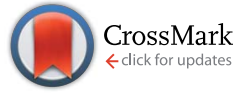

Cite this: RSC Adv., 2017, 7, 16428
Received 11th January 2017 Accepted 25th February 2017

DOI: $10.1039 / \mathrm{c} 7 \mathrm{ra00425 \textrm {g }}$

rsc.li/rsc-advances

\section{The effect of incorporating carboxylic acid functionalities into 2,2'-bipyridine on the biological activity of the complexes formed: synthesis, structure, DNA/protein interaction, antioxidant activity and cytotoxicity ${ }_{\dagger}^{\dagger}$}

Thangavel Sathiya Kamatchi, ${ }^{\text {af }}$ Nataraj Chitrapriya, ${ }^{\text {b }}$ Sarvana Loganthan Ashok Kumar, ${ }^{c}$ Jang Yoon Jung, ${ }^{c}$ Horst Puschmann, ${ }^{d}$ Frank R. Fronczek ${ }^{\mathrm{e}}$ and Karuppannan Natarajan*a

In order to find out the influence of carboxylic acid functionalities $(\mathrm{COOH})$ present at different positions in $2,2^{\prime}$-bipyridine on various biological activities such as DNA/protein binding, antioxidant activity and cytotoxicity, three new ruthenium(॥) complexes $\left[\mathrm{RuCl}_{2}(\mathrm{bpy})(\mathrm{S}-\mathrm{DMSO})_{2}\right]$ (1) (bpy $=2,2^{\prime}$-bipyridine), $\left[\mathrm{RuCl}_{2}\left(\mathrm{H}_{2} \mathrm{~L} 1\right)(\mathrm{S}-\mathrm{DMSO})_{2}\right]$ (2) $\left(\mathrm{H}_{2} \mathrm{~L} 1=2,2^{\prime}\right.$-bipyridine-4,4'-dicarboxylic acid) and $\left[\mathrm{RuCl}_{2}\left(\mathrm{H}_{2} \mathrm{~L} 2\right)(\mathrm{S}-\mathrm{DMSO})_{2}\right](3)$ $\left(\mathrm{H}_{2} \mathrm{~L} 2=2,2^{\prime}\right.$-bipyridine-5, $5^{\prime}$-dicarboxylic acid) have been synthesized and structurally characterized by analytical and spectral methods. The structures of 1 and 3 have been determined by single crystal X-ray diffraction studies, which revealed that both are a roughly regular octahedron with bipyridine/bipyridine dicarboxylic acid as neutral bidentate donors with the involvement of both the nitrogen atoms of the bipyridine ring. In vitro DNA binding studies of the complexes were carried out employing absorption titrations, fluorescence spectra, thermal melting, viscosity and circular dichroic measurements, which disclosed that all the complexes bind to CT-DNA via groove binding. The interactions of the complexes with bovine serum albumin (BSA) were also investigated using UV-visible, fluorescence and synchronous fluorescence spectroscopic measurements. The results indicated that the new complexes quench the intrinsic fluorescence of BSA protein in a static quenching mode. The assessment of free radical scavenging ability involving the DPPH radical, hydroxyl radical, nitric oxide radical, superoxide anion radical, and hydrogen peroxide and a metal chelating assay showed that the new complexes 2 and 3 possess excellent radical scavenging properties over 1 and standard antioxidants vitamin $\mathrm{C}$ and $\mathrm{BHT}$. The in vitro cytotoxic activity of the new ruthenium complexes has been validated against HCT-15, HeLa, SKOV3, MCF7 and SKMel2 human cancer cells by SRB assay and cytotoxic selectivity has been examined against NIH 3T3 and HEK 293 normal cells by MTT assay and compared with that of the ruthenium anticancer drug NAMI A and standard platinum drug, cisplatin. The results indicated that the new complexes 2 and 3 displayed substantial cytotoxic specificity towards cancer cells only. Incorporation of a carboxylic acid group in the bipyridine moiety has resulted in showing differences in DNA/protein binding affinity, efficiency in antioxidant activity and cytotoxicity.
${ }^{a}$ Department of Chemistry, Bharathiar University, Coimbatore 641046, India. E-mail: k_natraj6@yahoo.com; Fax:+91422 242238; Tel: +91422 2428319

${ }^{b}$ Department of Chemistry, Yeungnam University, Gyeongsan City, Gyeong-buk, 712749, Republic of Korea

${ }^{\circ}$ Department of Chemistry, GRT Institute of Engineering Technology, Tiruttani 631209, India

${ }^{d}$ Department of Chemistry, Durham University, Durham, DH1 3KE, UK

${ }^{e}$ Department of Chemistry, Louisiana State University, Baton Rouge, LA 70803, USA

${ }_{\text {Department }}$ of Chemistry, Sakthi College of Arts and Science for Women, Oddanchatram, Dindigul 624 619, India

$\dagger$ Electronic supplementary information (ESI) available: Fig. S1-S9 and Tables S1-S7. CCDC 869937 and 843881. For ESI and crystallographic data in CIF or other electronic format see DOI: 10.1039/c7ra00425g

\section{Introduction}

Cancer is one of the diseases that has tormented human beings throughout history, for which a wide variety of treatments have been implemented over the years, like surgical removal of tumors, radiation treatment and chemotherapy. ${ }^{1}$ Chemotherapy is done most effectively with platinum complexes and out of thousands of synthesized and evaluated Pt(II) complexes, only three of them, namely, cisplatin, carboplatin and oxaliplatin (Fig. 1) have only been approved for worldwide clinical practice and have enjoyed a huge clinical and commercial hit. ${ }^{2-4}$ Despite the widespread clinical use, chemotherapy with 


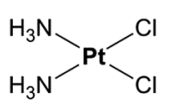

CISPLATIN

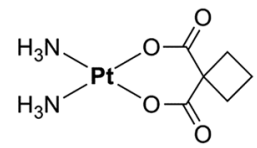

CARBOPLATIN

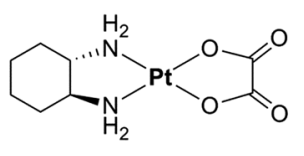

OXALIPLATIN

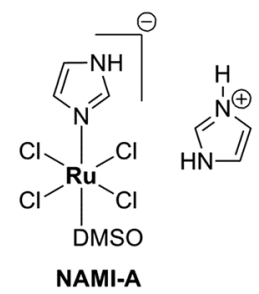

Fig. 1 Structures of some platinum and ruthenium chemotherapeutic complexes.

cisplatin and its analogues still has several drawbacks, in particular: (i) a relatively narrow spectrum of activity (ii) severe side-effects and (iii) acquired resistance. ${ }^{5}$ To overcome these problems, a search for new pharmaceutical agents featuring alternative metals has been undertaken. ${ }^{2,6}$ Among the several metals that are currently being investigated for their anticancer activity, ruthenium occupies a prominent position. ${ }^{6 a, 7}$ However, many of the ruthenium complexes are barely soluble in aqueous solution $^{6 a, 7 b, 8}$ and the solubility of ruthenium compounds has been increased by incorporating dialkylsulfoxide derivatives in the complexes as in $\left[\right.$ trans- $\left.\mathrm{RuCl}_{5}(\mathrm{DMSO}) \mathrm{Im}\right][\mathrm{ImH}]$ (NAMI-A) (Fig. 1), which is now recognized as the most successful ruthenium-based anticancer complex that has entered clinical trials. ${ }^{9}$ Hence, we attempted to synthesise new ruthenium complexes by incorporating the aforementioned key feature dimethylsulphoxide and also the DNA intercalating moiety bipyridine. Moreover, very little is known in the literature about the reactivity of $\mathrm{Ru}$-chloride-DMSO complexes toward carboxylate or dicarboxylate ligands. ${ }^{10}$ But, it is reported that an appropriate attachment of the carboxylic acid $(\mathrm{COOH})$ group in coordination complexes could modulate the solubility of the complex, cell transport and biological activity. ${ }^{11}$ This has inspired us to synthesize three new ruthenium complexes containing bipyridine and bipyridine dicarboxylic acids with DMSO as ancillary ligand.

It is a well known fact that DNA and protein are the major pharmacological targets of anticancer drugs, ${ }^{12}$ and hence, the objective of the present work is to understand in detail the DNA binding mode of the new complexes with the aid of different techniques. It has been proved that free radicals such as superoxide anion $\left(\mathrm{O}_{2}{ }^{-}\right)$, hydroxyl radical $\left(\mathrm{OH}^{\circ}\right)$ and hydrogen peroxide $\left(\mathrm{H}_{2} \mathrm{O}_{2}\right)$ can induce DNA damage in humans. This kind of damage to DNA has also been shown to contribute to aging and various diseases including cardiovascular, cancer and chronic inflammation. ${ }^{13,14}$ This has prompted us to test the synthesized complexes as free radical scavengers against various free radicals. Further, the in vitro anticancer activities of the synthesized complexes were also evaluated on a panel of cancer and normal cell lines.

\section{Experimental section}

\section{Materials and instrumentation}

All chemicals were reagent grade and were used as received from commercial suppliers unless otherwise stated. Commercially available $\mathrm{RuCl}_{3} \cdot 3 \mathrm{H}_{2} \mathrm{O}$ (Himedia) was used to prepare the starting complex. The starting complex cis-[$\left[\mathrm{RuCl}_{2}(\mathrm{DMSO})_{4}\right]$ was prepared according to the method reported by Evans et $a l .{ }^{15} 2,2^{\prime}-$ Bipyridine was purchased from Merck chemicals. 2,2'-Bipyridine-4,4'-dicarboxylic acid and 2,2'-bipyridine-5, $5^{\prime}$-dicarboxylic acid were purchased from Sigma-Aldrich. Melting points were determined with Lab India instrument. Elemental analyses of carbon, hydrogen, nitrogen and sulphur were performed on Vario EL III Elementar elemental analyzer. Electronic absorption spectra of the complexes were recorded using JASCO 600 spectrophotometer and emission measurements were carried out by using a JASCO FP-6600 spectrofluorometer. Nicolet Avatar Model FT-IR spectrophotometer was used to record the IR spectra $\left(4000-400 \mathrm{~cm}^{-1}\right)$ of the free ligands and complexes as $\mathrm{KBr}$ pellets. ${ }^{1} \mathrm{H}$ NMR spectra were recorded on Bruker AMX 500 at $500 \mathrm{MHz}$ using tetramethylsilane as an internal standard. The chemical shifts are expressed in parts per million (ppm). Calf thymus DNA (CT-DNA) was purchased from Sigma and dissolved in $5 \mathrm{mM}$ Tris-HCl buffer (pH 7.0) containing $100 \mathrm{mM}$ $\mathrm{NaCl}$ and $1 \mathrm{mM}$ EDTA. It was dialyzed several times against $5 \mathrm{mM}$ Tris-HCl buffer. All experiments involving interactions of complexes with CT-DNA were carried out in Tris $\mathrm{HCl}$ buffer $(\mathrm{pH}$ 7.0). Bovine serum albumin (BSA) and ethidium bromide (EB) were obtained from Sigma-Aldrich and used as received. Antioxidant activity measurements were done using UV spectrophotometer (UV-1800, Shimadzu).

\section{Synthesis of new ruthenium(II) complexes}

Synthesis of $\left[\mathrm{RuCl}_{\mathbf{2}}(\mathbf{b p y})(\mathrm{S}-\mathrm{DMSO})_{2}\right]$ (1). cis-[ $\left[\mathrm{RuCl}_{2}(\mathrm{DMSO})_{4}\right]$ $(0.100 \mathrm{~g}, 0.21 \mathrm{mmol})$ and the ligand $2,2^{\prime}$-bipyridine $(0.032 \mathrm{~g}, 0.21$ $\mathrm{mmol}$ ) were suspended in ethanol $(20 \mathrm{~mL}) .15 \mathrm{~min}$ at reflux was needed to solubilize both the metal and chelating partner. The resulting yellowish orange solution was maintained at reflux for five hours. Then the solution was allowed to stand for one week under air until orange crystals of the target complex was precipitated. Yield: $0.081 \mathrm{~g}, 80 \%$. Melting point: $193{ }^{\circ} \mathrm{C}$. Elemental analyses calculated for $\mathrm{C}_{14} \mathrm{H}_{20} \mathrm{~N}_{2} \mathrm{O}_{2} \mathrm{~S}_{2} \mathrm{Cl}_{2} \mathrm{Ru}$ : C, 34.71; $\mathrm{H}, 4.16$; N, 5.78; S, 13.24\%; found: C, 34.66; H, 4.16; N, 5.77; S, 13.25\%. FT-IR $\left(\mathrm{cm}^{-1}\right)$ in $\mathrm{KBr}: 1473 \nu(\mathrm{C}=\mathrm{C}), 1602 \nu(\mathrm{C}=\mathrm{N}), 1085$ $\nu(\mathrm{S}=\mathrm{O})_{\mathrm{s} \text {-bonded. }}$ UV-visible $\left(3 \% \mathrm{DMSO} / \mathrm{H}_{2} \mathrm{O}\right), \lambda_{\max }, \mathrm{nm}\left(\varepsilon, \mathrm{dm}^{3}\right.$ $\mathrm{mol}^{-1} \mathrm{~cm}^{-1}$ ): 243 (38 941), 287 (58 800), 320 (34 858), 343 (9400), 400 (6325). ${ }^{1} \mathrm{H}$ NMR $\delta_{\mathrm{H}}\left(\mathrm{CDCl}_{3}, \mathrm{ppm}\right): 3.58,3.55,3.24$, $2.68\left(4 \mathrm{~s},-\mathrm{CH}_{3}\right), 9.90\left(1 \mathrm{H}, \mathrm{d}, J=8.0 \mathrm{~Hz},=\mathrm{CH}_{6}\right), 9.73(1 \mathrm{H}, \mathrm{d}, J=$ $\left.8.0 \mathrm{~Hz},=\mathrm{CH}_{6^{\prime}}\right), 8.04\left(1 \mathrm{H}, \mathrm{t}, J=5.5, J=7.5 \mathrm{~Hz},=\mathrm{CH}_{5}\right), 7.93(1 \mathrm{H}$, $\left.\mathrm{t}, J=8 \mathrm{~Hz},=\mathrm{CH}_{5^{\prime}}\right), 7.63\left(1 \mathrm{H}, \mathrm{t}, J=7.0 \mathrm{~Hz},=\mathrm{CH}_{4}\right), 7.48(1 \mathrm{H}, \mathrm{dd}$, $\left.J=8.5 \mathrm{~Hz},=\mathrm{CH}_{4^{\prime}}\right), 8.19\left(1 \mathrm{H}, \mathrm{d}, J=7.0 \mathrm{~Hz},=\mathrm{CH}_{3}\right), 8.14(1 \mathrm{H}, \mathrm{d}, J$ $=7.5 \mathrm{~Hz},=\mathrm{CH}_{3^{\prime}}$ ). 
Synthesis of $\left[\operatorname{RuCl}_{2}\left(\mathbf{H}_{2} \mathbf{L 1}\right)(\mathrm{S}-\mathrm{DMSO})_{2}\right]$ (2). cis-[ $\left.\mathrm{RuCl}_{2}(\mathrm{DMSO})_{4}\right]$ $(0.100 \mathrm{~g}, 0.21 \mathrm{mmol})$ and the ligand 2,2'-bipyridine-4,4'-dicarboxylic acid $(0.050 \mathrm{~g}, 0.21 \mathrm{mmol})$ were heated under reflux in ethanol $(25 \mathrm{~mL})$ for $9 \mathrm{~h}$ whereby the solution turned from pale yellow to reddish brown. This solution was allowed to stand at room temperature for one week. The resulting orange red precipitate was filtered off, washed with ethanol, diethyl ether and dried under vacuum. The purity of the complex was checked by TLC ((99:5) chloroform-methanol) and attempts to isolate crystals suitable for single crystal XRD studies were unsuccessful. Yield: $0.085 \mathrm{~g}, 71 \%$. Melting point: $>300{ }^{\circ} \mathrm{C}$. Elemental analyses calculated for $\mathrm{C}_{16} \mathrm{H}_{20} \mathrm{~N}_{2} \mathrm{O}_{6} \mathrm{~S}_{2} \mathrm{Cl}_{2} \mathrm{Ru}$ : C, 33.57; H, 3.52; N, 4.89; S, 11.20\%; found: C, 33.51; H, 3.52; N, 4.89; S, 11.21\%. FT-IR ( $\left.\mathrm{cm}^{-1}\right)$ in $\mathrm{KBr}: 3387 \nu(\mathrm{COOH}), 1711 \nu(\mathrm{C}=\mathrm{O}), 1609$ $\nu(\mathrm{C}=\mathrm{N}), 1075 \nu(\mathrm{S}=\mathrm{O})_{\mathrm{s} \text {-bonded. }}$ UV-visible $\left(3 \% \mathrm{DMSO} / \mathrm{H}_{2} \mathrm{O}\right)$, $\lambda_{\max }, \mathrm{nm}\left(\varepsilon, \mathrm{dm}^{3} \mathrm{~mol}^{-1} \mathrm{~cm}^{-1}\right): 246$ (34 375), 300 (54 391), 331 (32 116), 405 (6775). ${ }^{1} \mathrm{H}$ NMR $\delta_{\mathrm{H}}\left(\mathrm{CDCl}_{3}, \mathrm{ppm}\right): 3.51,3.28,3.09$, $2.42\left(4 \mathrm{~s},-\mathrm{CH}_{3}\right), 9.29\left(1 \mathrm{H}, \mathrm{d}, J=8.5 \mathrm{~Hz},=\mathrm{CH}_{6}\right), 7.76(1 \mathrm{H}, \mathrm{d}, J=$ $\left.9.0 \mathrm{~Hz},=\mathrm{CH}_{6^{\prime}}\right), 7.98\left(1 \mathrm{H}, \mathrm{dd}, J_{\mathrm{o}}=7.5 \mathrm{~Hz}, J_{\mathrm{m}}=1.5 \mathrm{~Hz},=\mathrm{CH}_{5}\right)$, $7.07\left(1 \mathrm{H}, \mathrm{dd}, J_{\mathrm{o}}=8 \mathrm{~Hz}, J_{\mathrm{m}}=2.0 \mathrm{~Hz},=\mathrm{CH}_{5^{\prime}}\right), 8.59\left(1 \mathrm{H}, \mathrm{d}, J_{\mathrm{m}}=\right.$ $\left.2.0 \mathrm{~Hz},=\mathrm{CH}_{3}\right), 8.43\left(1 \mathrm{H}, \mathrm{d}, J_{\mathrm{m}}=2.0 \mathrm{~Hz},=\mathrm{CH}_{3^{\prime}}\right), 12.74,13.30$ $(2 \mathrm{~s},-\mathrm{COOH})$.

Synthesis of $\left[\mathrm{RuCl}_{2}\left(\mathrm{H}_{2} \mathbf{L 2}\right)(\mathrm{S}-\mathrm{DMSO})_{2}\right]$ (3). It was synthesized using the same procedure as described for $\mathbf{2}$ with the ligand $2,2^{\prime}$ bipyridine-5,5'-dicarboxylic acid $\left(\mathrm{H}_{2} \mathrm{~L} 2\right)(0.050 \mathrm{~g}, 0.21 \mathrm{mmol})$ and the precursor complex $(0.100 \mathrm{~g}, 0.21 \mathrm{mmol})$. Slow evaporation of the solvent after reduction to $50 \%$ gave orange crystals suitable for single crystal XRD studies. Yield: $0.092 \mathrm{~g}, 77 \%$. Melting point: $>300{ }^{\circ} \mathrm{C}$. Elemental analyses calculated for $\mathrm{C}_{16}-$ $\mathrm{H}_{20} \mathrm{~N}_{2} \mathrm{O}_{6} \mathrm{~S}_{2} \mathrm{Cl}_{2} \mathrm{Ru}$ : C, 33.57; H, 3.52; N, 4.89; S, $11.20 \%$; found: C, 33.49; $\mathrm{H}, 3.52 ; \mathrm{N}, 4.89 ; \mathrm{S}, 11.21 \%$. FT-IR $\left(\mathrm{cm}^{-1}\right)$ in $\mathrm{KBr}: 3375$ $\nu(\mathrm{COOH}), 1711 \nu(\mathrm{C}=\mathrm{O}), 1642 \nu(\mathrm{C}=\mathrm{N}), 1075 \nu(\mathrm{S}=\mathrm{O})_{\mathrm{S}-b o n d e d}$. UVvisible $\left(3 \% \mathrm{DMSO} / \mathrm{H}_{2} \mathrm{O}\right), \lambda_{\max }, \mathrm{nm}\left(\varepsilon, \mathrm{dm}^{3} \mathrm{~mol}^{-1} \mathrm{~cm}^{-1}\right): 254$ (24 691), 301 (53 425), 330 (25 250), 407 (3983). ${ }^{1} \mathrm{H}$ NMR $\delta_{\mathrm{H}}$ $\left(\mathrm{CDCl}_{3}, \mathrm{ppm}\right): 3.42,3.36,3.02,2.38\left(4 \mathrm{~s},-\mathrm{CH}_{3}\right), 10.27\left(1 \mathrm{H}, \mathrm{d}, J_{\mathrm{m}}\right.$ $\left.=2.0 \mathrm{~Hz},=\mathrm{CH}_{6}\right), 10.07\left(1 \mathrm{H}, \mathrm{d}, J_{\mathrm{m}}=2.0 \mathrm{~Hz},=\mathrm{CH}_{6^{\prime}}\right), 8.86(1 \mathrm{H}, \mathrm{d}$, $\left.J=8.0 \mathrm{~Hz},=\mathrm{CH}_{4}\right), 8.81\left(1 \mathrm{H}, \mathrm{d}, J=8.5 \mathrm{~Hz},=\mathrm{CH}_{4^{\prime}}\right), 8.63(1 \mathrm{H}, \mathrm{dd}$, $\left.J_{\mathrm{o}}=8.0 \mathrm{~Hz}, J_{\mathrm{m}}=2.0 \mathrm{~Hz},=\mathrm{CH}_{3}\right), 8.50\left(1 \mathrm{H}, \mathrm{dd}, J_{\mathrm{o}}=8.0 \mathrm{~Hz}, J_{\mathrm{m}}=\right.$ $\left.1.5 \mathrm{~Hz},=\mathrm{CH}_{3^{\prime}}\right), 13.49,13.91(2 \mathrm{~s},-\mathrm{COOH})$.

\section{X-ray crystallography}

X-ray diffraction measurements of complex 1 were performed on a Xcalibur, Sapphire3, Gemini ultra diffractometer. The crystal was kept at $120 \mathrm{~K}$ during data collection. Using Olex $2{ }^{16}$ the structure was solved with the Olex2.solve ${ }^{17}$ structure solution program using charge flipping and refined with the SHELXL $^{18}$ refinement package using least squares minimization. X-ray diffraction measurements of complex 3 were performed at $95 \mathrm{~K}$ on a Nonius Kappa CCD diffractometer equipped with graphite monochromated Mo K $\alpha$ radiation and an Oxford Cryostream cryostat at temperature. The structures of the complexes were solved by direct methods and refinements were carried out by using full matrix least-squares techniques. The hydrogen atoms were generally visible in difference maps and were placed in idealized positions and treated as riding in the refinements, except for those on one water molecule, for which coordinates were refined. For the other two water molecules, $\mathrm{H}$ atoms were not located. The following computer programs were used: structure solution SIR-97, ${ }^{19}$ refinement SHELXL-97, 18 molecular diagrams and ORTEP-3 (ref. 20) for Windows.

\section{DNA binding experiments}

The concentrations of DNA and the new complexes 1-3 were determined spectrophotometrically using their extinction coefficients $\varepsilon_{258 \mathrm{~nm}}=6700 \mathrm{M}^{-1} \mathrm{~cm}^{-1}, \varepsilon_{287} \mathrm{~nm}=58800 \mathrm{M}^{-1}$ $\mathrm{cm}^{-1}, \varepsilon_{300 \mathrm{~nm}}=54391 \mathrm{M}^{-1} \mathrm{~cm}^{-1}$ and $\varepsilon_{301 \mathrm{~nm}}=53425 \mathrm{M}^{-1}$ $\mathrm{cm}^{-1}$ respectively. The experiments were carried out in $5 \mathrm{mM}$ Tris-HCl buffer ( $\mathrm{pH}$ 7.0) at ambient temperature and the complexes were dissolved in $5 \mathrm{mM}$ Tris- $\mathrm{HCl}$ buffer containing $3 \%$ DMSO. Changes in the fluorescence emission spectrum of the ethidium bromide-DNA complex were recorded under various complex concentrations. The fluorescence spectra in the fluorimeter were obtained at an excitation wavelength of $522 \mathrm{~nm}$ and an emission wavelength of $584 \mathrm{~nm}$. Melting profiles were measured at $260 \mathrm{~nm}$ by a Cary 300 spectrophotometer. Readings were recorded for every $2{ }^{\circ} \mathrm{C}$ raise in temperature per minute. The viscosity measurement was carried out using an Ubbelohde viscometer immersed in a thermostatic water bath maintained at $25 \pm 0.1^{\circ} \mathrm{C}$. DNA samples with approximately 200 base pairs in length were prepared by sonication in order to minimize complexities arising from DNA flexibility. Flow times were measured with a digital stopwatch; each sample was measured three times, and an average flow time was calculated. Relative viscosities for CT-DNA in the presence and absence of the complex were calculated from the relation $\eta=\left(t-t_{0}\right) / t_{0}$, where $t$ is the observed flow time of DNA-containing solution and $t_{0}$ is the flow time of Tris- $\mathrm{HCl}$ buffer alone. Data are presented as $\left(\eta / \eta_{0}\right)^{1 / 3}$ versus binding ratio, where $\eta$ is the viscosity of CT-DNA in the presence of complex and $\eta_{0}$ is the viscosity of CTDNA alone.

\section{Protein binding studies}

Binding of the complexes with bovine serum albumin (BSA) was studied from the fluorescence spectra recorded with an excitation wavelength of at $280 \mathrm{~nm}$ and the corresponding emission at $345 \mathrm{~nm}$ assignable to that of BSA. The excitation and emission slit widths and scan rates were maintained constant for all of the experiments. A stock solution of BSA was prepared in $50 \mathrm{mM}$ phosphate buffer $(\mathrm{pH}=7.2)$ and stored in the dark at $4{ }^{\circ} \mathrm{C}$ for further use. A concentrated stock solution of the complexes was prepared as mentioned for the DNA binding experiments, except that the phosphate buffer was used instead of a Tris-HCl buffer for all of the experiments. In all the experiments the concentration of BSA was kept constant at $1 \mu \mathrm{M}$ and complexes 1-3 were varied from $0-30 \mu \mathrm{M}$. Titrations were manually done by using a micropipette for the addition of the complexes. For synchronous fluorescence spectra also, the same concentrations of BSA and the complexes were used and the spectra were measured at two different $\Delta \lambda$ values (difference between the excitation and emission wavelengths of BSA), such as 15 and $60 \mathrm{~nm}$. 


\section{Antioxidant assays}

The ability of ruthenium complexes to act as hydrogen donors or free radical scavengers was tested by conducting a series of in vitro antioxidant assays involving DPPH radical, hydroxyl radical, nitric oxide radical, hydrogen peroxide, superoxide anion radical, metal chelating assay and the results were compared with that of standard antioxidants including natural antioxidant vitamin $\mathrm{C}$ and synthetic antioxidant BHT (Butylated Hydroxy Toluene).

The DPPH radical scavenging activity of the complexes was measured according to the method of Blois. ${ }^{21}$ The DPPH radical is a stable free radical and due to the presence of an odd electron, it shows a strong absorption band at $517 \mathrm{~nm}$ in visible spectrum. If this electron becomes paired off in the presence of a free radical scavenger, this absorption vanishes resulting in decolorization stoichiometrically with respect to the number of electrons taken up. Various concentrations of the experimental complexes were taken and the volumes were adjusted to $100 \mu \mathrm{L}$ with methanol. About $5 \mathrm{~mL}$ of $0.1 \mathrm{mM}$ methanolic solution of DPPH was added to the aliquots of samples and standards (BHT and vitamin C) and shaken vigorously. Negative control was prepared by adding $100 \mu \mathrm{L}$ of methanol in $5 \mathrm{~mL}$ of $0.1 \mathrm{mM}$ methanolic solution DPPH. The tubes were allowed to stand for $20 \mathrm{~min}$ at $27^{\circ} \mathrm{C}$. The absorbance of the sample was measured at $517 \mathrm{~nm}$ against the blank (methanol).

The hydroxyl radical scavenging activity of the complex has been investigated by using the Nash method. ${ }^{22}$ In vitro hydroxyl radicals were generated by $\mathrm{Fe}^{3+} /$ ascorbic acid system. The detection of hydroxyl radicals was carried out by measuring the amount of formaldehyde formed from the oxidation reaction with DMSO. The formaldehyde produced was detected spectrophotometrically at $412 \mathrm{~nm}$. In a typical experiment, a mixture of $1.0 \mathrm{~mL}$ of iron-EDTA solution $(0.13 \%$ ferrous ammonium sulfate and $0.26 \%$ EDTA), $0.5 \mathrm{~mL}$ of EDTA solution (0.018\%), and $1.0 \mathrm{~mL}$ of DMSO (0.85\% DMSO (v/v) in 0.1 M phosphate buffer, $\mathrm{pH} 7.4$ ) were sequentially added in the test tubes which contains fixed concentration of the test compounds. The reaction was initiated by adding $0.5 \mathrm{~mL}$ of ascorbic acid $(0.22 \%)$ and was incubated at $80-90{ }^{\circ} \mathrm{C}$ for $15 \mathrm{~min}$ in a water bath. After incubation, the reaction was terminated by the addition of $1.0 \mathrm{~mL}$ of ice-cold trichloroacetic acid $(17.5 \% \mathrm{w} / \mathrm{v})$. Subsequently, $3.0 \mathrm{~mL}$ of Nash reagent was added to each tube and left at room temperature for $15 \mathrm{~min}$. The intensity of the colour formed was measured spectrophotometrically at $412 \mathrm{~nm}$ against the reagent blank.

Assay of nitric oxide ( $\mathrm{NO}^{\circ}$ ) scavenging activity is based on the method, ${ }^{23}$ where sodium nitroprusside in aqueous solution at physiological $\mathrm{pH}$ spontaneously generates nitric oxide, which interacts with oxygen to produce nitrite ions. This can be estimated using Griess reagent. Scavengers of nitric oxide compete with oxygen leading to reduced production of nitrite ions. For the experiment, sodium nitroprusside $(10 \mathrm{mM})$ in phosphate buffered saline was mixed with a fixed concentration of the complex, standards and incubated at room temperature for $150 \mathrm{~min}$. After the incubation period, $0.5 \mathrm{~mL}$ of Griess reagent containing $1 \%$ sulfanilamide, $2 \% \mathrm{H}_{3} \mathrm{PO}_{4}$ and $0.1 \% \mathrm{~N}$-(1-naphthyl) ethylenediamine dihydrochloride was added. The absorbance of the chromophore formed was measured at $546 \mathrm{~nm}$.
The ability of the complexes to scavenge hydrogen peroxide was determined using the method of Ruch et al. ${ }^{\mathbf{2 4}}$ In a typical experiment, a solution of hydrogen peroxide $(2.0 \mathrm{mM})$ was prepared in phosphate buffer $(0.2 \mathrm{M}, \mathrm{pH} 7.4)$ and its concentration was determined spectrophotometrically from absorption at $230 \mathrm{~nm}$ with molar absorptivity $81 \mathrm{M}^{-1} \mathrm{~cm}^{-1}$. The complexes $\left(100 \mu \mathrm{g} \mathrm{mL}{ }^{-1}\right)$, BHT and vitamin $\mathrm{C}\left(100 \mu \mathrm{g} \mathrm{mL} \mathrm{m}^{-1}\right)$ were added to $3.4 \mathrm{~mL}$ of phosphate buffer prepared above together with hydrogen peroxide solution $(0.6 \mathrm{~mL})$. An identical reaction mixture without the sample was taken as negative control. Absorbance of hydrogen peroxide at $230 \mathrm{~nm}$ was determined after $10 \mathrm{~min}$ against the blank (phosphate buffer).

The superoxide anion radical $\left(\mathrm{O}_{2}{ }^{-\cdot}\right)$ scavenging assay is based on the capacity of the complexes to inhibit formazan formation by scavenging the superoxide radicals generated in riboflavin-light-NBT system. ${ }^{25}$ In a typical experiment, a $3 \mathrm{~mL}$ reaction mixture contained $50 \mathrm{mM}$ sodium phosphate buffer (pH 7.6), $20 \mu \mathrm{g}$ riboflavin, $12 \mathrm{mM}$ EDTA, $0.1 \mathrm{mg}$ NBT and $1 \mathrm{~mL}$ complex solution $\left(20-100 \mu \mathrm{g} \mathrm{mL}^{-1}\right)$. Reaction was started by illuminating the reaction mixture with different concentrations of complex for $90 \mathrm{~s}$. Immediately after illumination, the absorbance was measured at $590 \mathrm{~nm}$. The entire reaction assembly was enclosed in a box lined with aluminium foil. Identical tubes with reaction mixture kept in dark served as blanks.

The chelation with ferrous ions by the experimental complexes was estimated by the method of Dinis et $a .^{26}$ Initially, about $100 \mu \mathrm{L}$ of the samples and the standards were added to $50 \mu \mathrm{L}$ solution of $2 \mathrm{mM} \mathrm{FeCl}_{2}$. The reaction was initiated by the addition of $200 \mu \mathrm{L}$ of $5 \mathrm{mM}$ ferrozine and the mixture was shaken vigorously and left standing at room temperature for $10 \mathrm{~min}$. Absorbance of the solution was then measured spectrophotometrically at $562 \mathrm{~nm}$ against the blank (deionized water).

For the above six assays, all the tests were run in triplicate and the percentage activity was calculated with the help of the following equation

$$
\text { Scavenging activity }(\%)=\left[\left(A_{0}-A_{1}\right) / A_{0}\right] \times 100
$$

where, $A_{0}$ is the absorbance of the control and $A_{1}$ is the absorbance of the complex/standard.

When the inhibition of the tested compounds is $50 \%$, the tested compound concentration is $\mathrm{IC}_{50}$.

\section{In vitro anticancer activity evaluation}

SRB assay. The cell lines were grown in RPMI-1640 medium containing $10 \%$ fetal bovine serum and $2 \mathrm{mM}$-glutamine. For the screening experiment, cells were inoculated into 96 well microtiter plates in $90 \mu \mathrm{L}$ at plating densities, depending on the doubling time of individual cell lines. After cell inoculation, the microtiter plates were incubated at $37{ }^{\circ} \mathrm{C}, 5 \% \mathrm{CO}_{2}, 95 \%$ air and $100 \%$ relative humidity for $24 \mathrm{~h}$ prior to addition of experimental compounds. After $24 \mathrm{~h}$, one plate of each cell line was fixed in situ with TCA, to represent a measurement of the cell population for each cell line at the time of compound addition. NAMI A, cisplatin and the complexes to be tested were dissolved in dimethylsulphoxide and stored frozen prior to use. The 
cytotoxicity assay was done against HeLa (human cervix cancer), HCT-15 (human colon tumor), SKOV3 (human ovarian adenocarcinoma), MCF7 (human breast cancer), SKMel2 (human skin melanoma) cell lines which were obtained from National Centre for Cell Science (NCCS), Pune, India. Cell viability was carried out using colorimetric SRB assay method. Solutions of different concentration of the test compounds under test were added to the cell monolayer. Triplicate wells were prepared for each individual concentration. After compound addition, plates were incubated at standard conditions for $48 \mathrm{~h}$ and assay was terminated by the addition of cold trichloroacetic acid (TCA). Cells were fixed in situ by the gentle addition of $50 \mu \mathrm{L}$ of cold $30 \%(\mathrm{w} / \mathrm{v})$ TCA (final concentration, 10\% TCA) and incubated for $60 \mathrm{~min}$ at $4{ }^{\circ} \mathrm{C}$. Sulforhodamine B (SRB) solution $(50 \mu \mathrm{L})$ at $0.4 \%(\mathrm{w} / \mathrm{v})$ in $1 \%$ acetic acid was added to each of the wells, and plates were incubated for $20 \mathrm{~min}$ at room temperature. After staining, unbound dye was recovered and the residual dye was removed by washing five times with $1 \%$ acetic acid. Bound stain was subsequently eluted with $10 \mathrm{mM}$ tris base $(\mathrm{pH} 10.5)$ for 5 min. The absorbance was read on an Elisa plate reader at a wavelength of $540 \mathrm{~nm}$ with $690 \mathrm{~nm}$ as reference wavelength. The results were expressed as the concentration at which there was $50 \%$ inhibition $\left(\mathrm{IC}_{50}\right)$.

MTT assay. The cytotoxicity assay was done against NIH 3T3 (mouse embryonic fibroblasts) and HEK 293 (Human Embryonic Kidney 293 cells), which were obtained from National Centre for Cell Science (NCCS), Pune, India. Cell viability was carried out using the MTT assay. The cells were grown in Dulbeccos modified Eagles medium (DMEM) containing 10\% FBS. For screening experiments, the cells were seeded into 96-well plates in $100 \mu \mathrm{L}$ of respective medium containing $10 \%$ FBS, at plating density of 10000 cells per well and incubated at $37{ }^{\circ} \mathrm{C}, 5 \% \mathrm{CO}_{2}, 95 \%$ air and $100 \%$ relative humidity for $24 \mathrm{~h}$ prior to addition of complexes and the standard drugs NAMI A and cisplatin. The test compounds were dissolved in DMSO and diluted in respective medium containing 1\% FBS. After $24 \mathrm{~h}$, the medium was replaced with respective medium with $1 \%$ FBS containing the test compounds at various concentration and incubated at $37{ }^{\circ} \mathrm{C}, 5 \% \mathrm{CO}_{2}, 95 \%$ air and $100 \%$ relative humidity for $48 \mathrm{~h}$. Triplicate was maintained and the medium without the test compounds was served as control. After $48 \mathrm{~h}, 10 \mu \mathrm{L}$ of MTT ( $5 \mathrm{mg} \mathrm{mL} \mathrm{mL}^{-1}$ ) in phosphate buffered saline (PBS) was added to each well and incubated at $37^{\circ} \mathrm{C}$ for $4 \mathrm{~h}$. The medium with MTT was then flicked off and the formed formazan crystals were dissolved in $100 \mu \mathrm{L}$ of DMSO and then measured the absorbance at $570 \mathrm{~nm}$ using micro plate reader. The \% cell inhibition was determined using the following formula, and a graph was plotted between \% of cell inhibition and concentration. From this plot, the $\mathrm{IC}_{50}$ value was calculated.

$\%$ inhibition $=[$ mean OD of untreated cells $($ control $) /$ mean OD of treated cells (control) $] \times 100$.

\section{Results and discussion}

\section{Synthesis and characterization of the complexes}

The straightforward reactions of the bipyridine (bpy) and bipyridine dicarboxylic acids $\left(\mathrm{H}_{2} \mathrm{LI} / \mathrm{H}_{2} \mathrm{~L} 2\right)$ with cis- $\left[\mathrm{RuCl}_{2}(-\right.$ DMSO $\left.)_{4}\right]$ gave new complexes of the types $\left[\mathrm{RuCl}_{2}(\mathrm{bpy})(\mathrm{S}-\right.$ DMSO $\left.)_{2}\right]$ and $\left[\mathrm{RuCl}_{2}\left(\mathrm{H}_{2} \mathrm{~L}\right)(\mathrm{S}-\mathrm{DMSO})_{2}\right]$ where $\mathrm{H}_{2} \mathrm{~L}=\mathrm{H}_{2} \mathrm{~L} 1 / \mathrm{H}_{2} \mathrm{~L} 2$ as sketched out in Scheme 1. The complexes are diamagnetic corresponding to bivalent state of ruthenium (low-spin $\mathrm{d}^{6}, S=$ $0)$. The complexes were stable to air and light, non-hygroscopic in nature and were remarkably soluble in $\mathrm{CHCl}_{3}, \mathrm{CH}_{2} \mathrm{Cl}_{2}$, $\mathrm{CH}_{3} \mathrm{CN}$, DMF and DMSO. These complexes were synthesized in good yields and characterized by elemental analysis, IR and ${ }^{1} \mathrm{H}$ NMR spectroscopic techniques. The retention of the IR band around $3375-3387 \mathrm{~cm}^{-1}$ in 2 and 3 confirms the non participation of $\mathrm{COOH}$ group of bipyridine dicarboxylic acid in coordination, which is consistent with the results of NMR and X-ray analysis. ${ }^{1} \mathrm{H}$ NMR spectrum of the complex $\mathbf{1}$ is given in Fig. S1 $(\mathrm{ESI} \dagger)$. It has been observed that a molecule of the ligands (bpy,

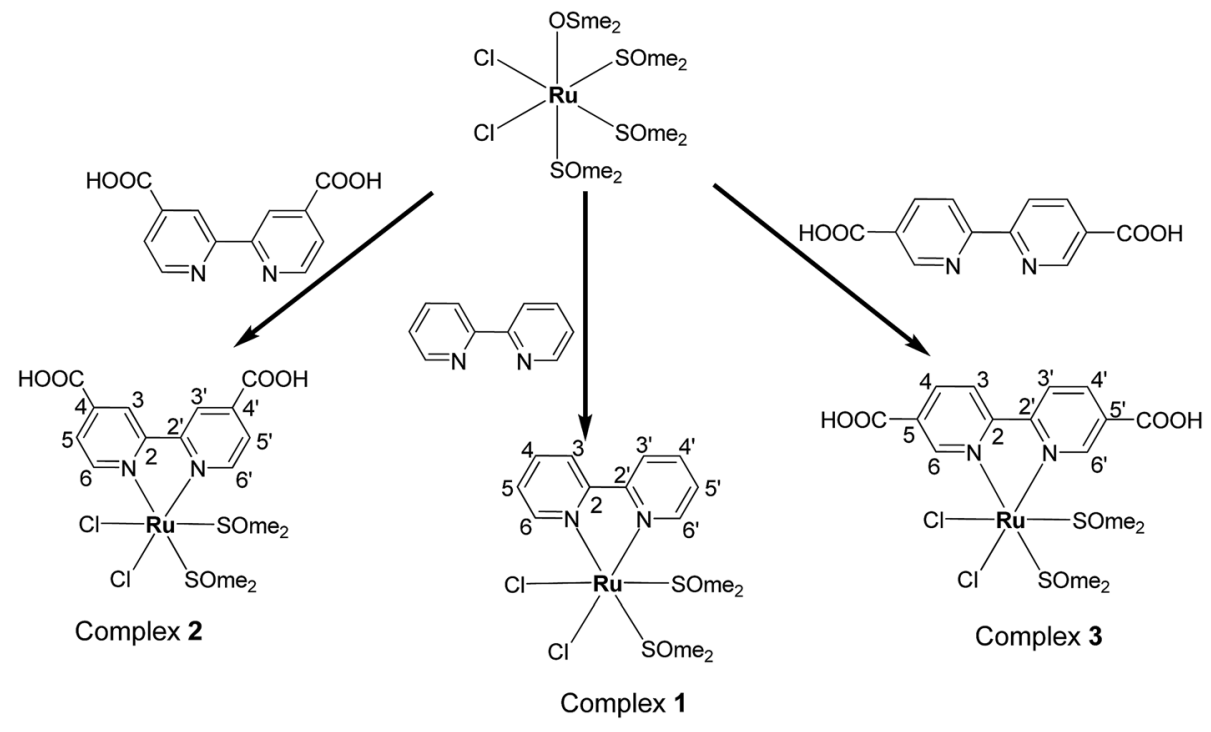

Scheme 1 General scheme for the synthesis of new ruthenium(॥) complexes. 
$\mathrm{H}_{2} \mathrm{~L} 1$ and $\mathrm{H}_{2} \mathrm{~L} 2$ ) replaced an S-bonded DMSO and an O-bonded DMSO from the precursor complex cis-[ $\mathrm{RuCl}_{2}(\mathrm{O}-\mathrm{DMSO})(\mathrm{S}-$ DMSO $\left.)_{3}\right]$. The solid state structure of the complexes $\mathbf{1}$ and $\mathbf{3}$ were determined by single crystal X-ray crystallographic studies. It revealed that bipyridine and bipyridine dicarboxylic acid were coordinated to the metal ion as neutral bidentate NN donors.

\section{X-ray crystallography}

The molecular structures of complexes 1 and $\mathbf{3}$ were established by single crystal X-ray analysis. The ORTEP diagrams with the atom numbering scheme of $\mathbf{1}$ and $\mathbf{3}$ are displayed in Fig. 2 and 3 respectively. The relevant details concerning the data collection and structure refinement of the complexes were summarized in Table 1 and selected geometrical parameters (inter atomic distances and angles) are given Table S1 (ESI $\dagger$ ). Numerous ruthenium complexes with two or three $\mathrm{N}-\mathrm{N}$ ligands are known, but examples of mono $(\mathrm{N}-\mathrm{N})$ complexes remain scarce, because it is difficult to prevent ligand redistribution during synthesis. The precursor contains three S-bonded DMSO's and one O-bonded DMSO and the structural formula can be written as cis, fac $-\left[\mathrm{RuCl}_{2}(\mathrm{DMSO})_{3}(-\right.$ DMSO)]. The O-bonded DMSO is the most labile ligand in cis, fac- $\left[\mathrm{RuCl}_{2}(\mathrm{DMSO})_{3}(\mathrm{DMSO})\right]$ and is selectively replaced by stronger $\sigma$ - and $\pi$-donors (L) leaving the geometry of the resulting complex unchanged forming cis, fac-[ $\mathrm{RuCl}_{2}(-$ $\left.\mathrm{DMSO})_{3}(\mathrm{~L})\right]$. With the chelating ligands $\left(\mathrm{LL}^{\prime}\right)$, displacement of

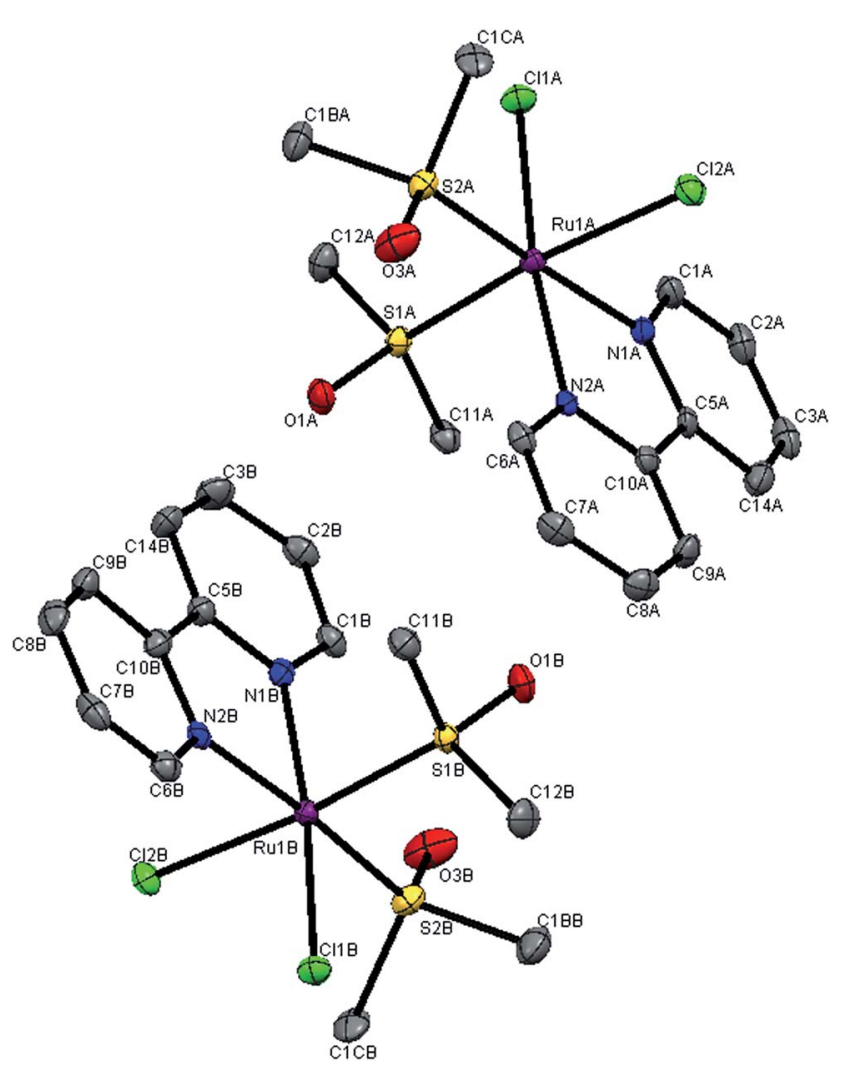

Fig. 2 X-ray crystal structure with atom numbering scheme for complex 1 as thermal ellipsoids at 50\% probability level. The hydrogen atoms have been omitted for clarity.

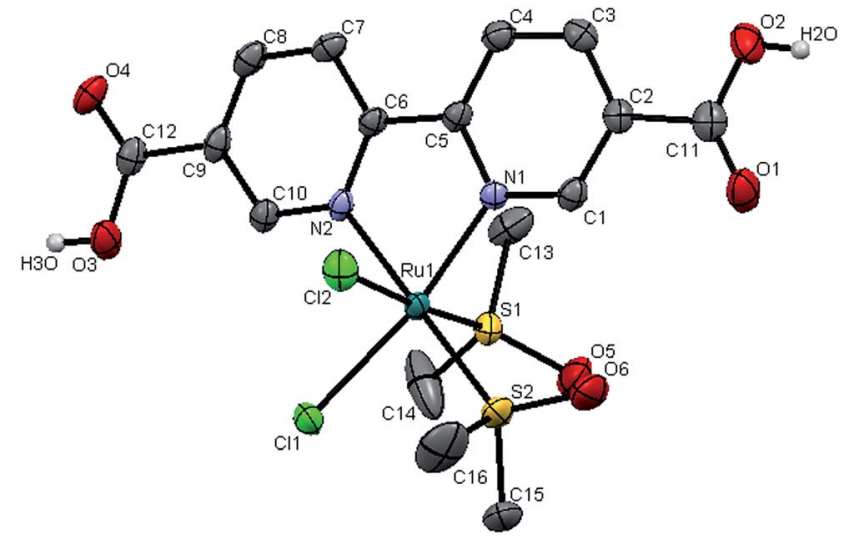

Fig. 3 X-ray crystal structure with atom numbering scheme for complex 3 as thermal ellipsoids at 50\% probability level. The hydrogen atoms have been (except carboxylic acid protons) omitted for clarity.

the more weakly held O-bonded DMSO occurs first followed by the displacement of a DMSO ligand cis to it.

\section{Crystal structure of the complexes 1 and 3}

The crystal structures of the complexes $\mathbf{1}$ and $\mathbf{3}$ were obtained by examining the nice crystals obtained in the course of slow evaporation. From unit cell dimensions, it is clear that the crystal system of complex 1 is orthorhombic belonging to the space group $\mathrm{Pca}_{1}$ whereas complex 3 is crystallized in monoclinic space group $P 2_{1} / c$. In complex 1 , there are two independent complex molecules in the asymmetric unit, related by an approximate inversion center near $1 / 8,3 / 4, z$, as shown in the ORTEP diagram 2 . This is the most common location for local centers in this space group. ${ }^{27}$ For the new complexes, the coordination sphere around ruthenium centre constitutes distorted octahedron with coordination of bipyridine $\mathrm{N}-\mathrm{N}$ atoms with bite angles $\mathrm{N}(1 \mathrm{~A})-\mathrm{Ru}(1 \mathrm{~A})-\mathrm{N}(2 \mathrm{~A})=78.17(19)^{\circ}, \mathrm{N}(1 \mathrm{~B})-\mathrm{Ru}(1 \mathrm{~B})-\mathrm{N}(2 \mathrm{~B})=$ $78.84(19)^{\circ}$ for complex 1 and $\mathrm{N}(1)-\mathrm{Ru}(1)-\mathrm{N}(2)=78.7(1)^{\circ}$ for complex 3. The two S-coordinated DMSO molecules and the two chloride ions in the coordination sphere were found to be cis pairs. The basal plane is constructed of two nitrogen atoms of the bipyridine ligand, a chloride and an S-bonded DMSO. The remaining apical coordination sites are filled up by a chloride and an S-bonded DMSO. The distortion in the complex from ideal octahedral geometry is due to the customary small bite angle of the NN chelate and the bending of somewhat bulky chloride and a DMSO ligands towards the chelate, which is evident from the angles $\mathrm{N}(1 \mathrm{~A})-\mathrm{Ru}(1 \mathrm{~A})-\mathrm{N}(2 \mathrm{~A})=78.17(19)^{\circ}, \mathrm{N}(1 \mathrm{~B})-$ $\mathrm{Ru}(1 \mathrm{~B})-\mathrm{N}(2 \mathrm{~B})=78.84(19)^{\circ}$ [smaller than $\mathrm{S}(1 \mathrm{~A})-\mathrm{Ru}(1 \mathrm{~A})-\mathrm{S}(2 \mathrm{~A})=$ $92.68(6)^{\circ} ; \mathrm{S}(1 \mathrm{~B})-\mathrm{Ru}(1 \mathrm{~B})-\mathrm{S}(2 \mathrm{~B})=93.80(6)^{\circ}$ and $\mathrm{Cl}(1 \mathrm{~A})-\mathrm{Ru}(1 \mathrm{~A})-$ $\left.\mathrm{Cl}(2 \mathrm{~A})=89.31(5)^{\circ} ; \mathrm{Cl}(1 \mathrm{~B})-\mathrm{Ru}(1 \mathrm{~B})-\mathrm{Cl}(2 \mathrm{~B})=90.39(5)^{\circ}\right]$ and $\mathrm{S}(1 \mathrm{~A})-$ $\mathrm{Ru}(1 \mathrm{~A})-\mathrm{Cl}(2 \mathrm{~A})=174.17(6)^{\circ}, \mathrm{S}(1 \mathrm{~B})-\mathrm{Ru}(1 \mathrm{~B})-\mathrm{Cl}(2 \mathrm{~B})=174.58(6)^{\circ}$ in complex 1, where as $\mathrm{N}(1)-\mathrm{Ru}(1)-\mathrm{N}(2)=78.70(1)^{\circ}$ [smaller than $\mathrm{S} 1-\mathrm{Ru}(1)-\mathrm{S}(2)=92.94(4)^{\circ}$ and $\left.\mathrm{Cl}(1)-\mathrm{Ru}(1)-\mathrm{Cl}(2)=89.55(4)^{\circ}\right]$ and $\mathrm{S}(1)-\mathrm{Ru}(1)-\mathrm{Cl}(2)=175.96(4)^{\circ}$ in complex 3 . The average $\mathrm{Ru}-\mathrm{Cl}$ bond lengths in complex $1, \operatorname{Ru}(1)-\mathrm{Cl}(1)=2.427 \AA$ 政 $\mathrm{Ru}(1)-\mathrm{Cl}(2)=$ $2.426 \AA[\operatorname{Ru}(1 \mathrm{~A})-\mathrm{Cl}(1 \mathrm{~A})=2.4229(14), \operatorname{Ru}(1 \mathrm{~A})-\mathrm{Cl}(2 \mathrm{~A})=2.4310(15)$, $\mathrm{Ru}(1 \mathrm{~B})-\mathrm{Cl}(1 \mathrm{~B})=2.4209(15), \mathrm{Ru}(1 \mathrm{~B})-\mathrm{Cl}(2 \mathrm{~B})=2.43091(16)]$ and in 
Table 1 Crystallographic data for complexes 1 and 3

\begin{tabular}{|c|c|c|}
\hline & Complex 1 & Complex 3 \\
\hline CCDC deposit number & 869937 & 843881 \\
\hline Empirical formula & $\mathrm{C}_{14} \mathrm{H}_{20} \mathrm{Cl}_{2} \mathrm{~N}_{2} \mathrm{O}_{2} \mathrm{RuS}_{2}$ & $\mathrm{C}_{16} \mathrm{H}_{26} \mathrm{Cl}_{2} \mathrm{~N}_{2} \mathrm{O}_{9} \mathrm{RuS}_{2}$ \\
\hline Formula weight & 484.41 & 626.48 \\
\hline Temperature/K & $120.0(2)$ & $95.0(5)$ \\
\hline Crystal system & Orthorhombic & Monoclinic \\
\hline Space group & $\mathrm{PCa}_{1}$ & $P 2_{1} / c$ \\
\hline$a / \AA$ & $27.7264(7)$ & $13.794(2)$ \\
\hline$b / \AA$ & $7.7631(3)$ & $12.924(2)$ \\
\hline$c / \AA ̊ \AA$ & $16.5025(7)$ & $14.1348(15)$ \\
\hline$\alpha /^{\circ}$ & 90 & 90 \\
\hline$\beta /^{\circ}$ & 90 & $114.513(7)$ \\
\hline$\gamma /{ }^{\circ}$ & 90 & 90 \\
\hline Volume $/ \AA^{3}$ & $3552.1(2)$ & $2292.7(5)$ \\
\hline$Z$ & 8 & 4 \\
\hline$\rho_{\text {calc }} \mathrm{mg} \mathrm{mm}^{-3}$ & 1.812 & 1.815 \\
\hline $\mathrm{m} / \mathrm{mm}^{-1}$ & 1.427 & 1.150 \\
\hline$F(000)$ & 1952 & 1272 \\
\hline Crystal size $/ \mathrm{mm}^{3}$ & $0.47 \times 0.36 \times 0.26$ & $0.25 \times 0.10 \times 0.10$ \\
\hline $\begin{array}{l}2 \theta \text { range for } \\
\text { data collection }\end{array}$ & 5.25 to $52^{\circ}$ & 6.24 to $61^{\circ}$ \\
\hline Index ranges & $\begin{array}{l}-34 \leq h \leq 34 \\
-9 \leq k \leq 9 \\
-20 \leq l \leq 20\end{array}$ & $\begin{array}{l}-18 \leq h \leq 19 \\
-11 \leq k \leq 18 \\
-19 \leq l \leq 18\end{array}$ \\
\hline Reflections collected & 46162 & 24867 \\
\hline Independent reflections & $\begin{array}{l}6978 \\
{[R(\text { int })=0.0526]}\end{array}$ & $\begin{array}{l}6251 \\
{[R(\mathrm{int})=0.0208]}\end{array}$ \\
\hline Data/restraints/parameters & $6978 / 1 / 423$ & $6251 / 0 / 302$ \\
\hline Goodness-of-fit on $F^{2}$ & 1.128 & 1.013 \\
\hline Final $R$ indexes $[I \geq 2 \sigma(I)]$ & $\begin{array}{l}R_{1}=0.0292 \\
\mathrm{w} R_{2}=0.0703\end{array}$ & $\begin{array}{l}R_{1}=0.0479 \\
\mathrm{w} R_{2}=0.1064\end{array}$ \\
\hline Final $R$ indexes [all data] & $\begin{array}{l}R_{1}=0.0301 \\
\mathrm{w} R_{2}=0.0709\end{array}$ & $\begin{array}{l}R_{1}=0.0633 \\
\mathrm{w} R_{2}=0.1151\end{array}$ \\
\hline $\begin{array}{l}\text { Largest diff. } \\
\text { peak/hole } / \mathrm{e} \AA^{-3}\end{array}$ & $2.31 /-0.72$ & $1.79 /-1.32$ \\
\hline
\end{tabular}

complex 3, $\mathrm{Ru}(1)-\mathrm{Cl}(1)=2.414(1) \AA$; $\mathrm{Ru}(1)-\mathrm{Cl}(2)=2.4289$ (9) $\AA$ is comparable with that of $c i s, f a c-\left[\mathrm{RuCl}_{2}(\mathrm{DMSO})_{3}(\mathrm{DMSO})\right]$ (average $\mathrm{Ru}-\mathrm{Cl}=2.42 \AA)^{28}$ and other $\mathrm{Ru}(\mathrm{II})-\mathrm{DMSO}-\mathrm{Cl}$ complexes. ${ }^{29,30}$ The geometry of the coordinated DMSO is approximately tetrahedral with angles ranging from 111 to $119^{\circ}$ in the two complexes. The $\mathrm{Ru}-\mathrm{S}$ bond lengths [for $1, \mathrm{Ru}(1 \mathrm{~A})-\mathrm{S}(1 \mathrm{~A})=2.2322(15)$; $\mathrm{Ru}(1 \mathrm{~A})-$ $\mathrm{S}(2 \mathrm{~A})=2.2888(16) ; \mathrm{Ru}(1 \mathrm{~B})-\mathrm{S}(1 \mathrm{~B})=2.2366(15) ; \mathrm{Ru}(1 \mathrm{~B})-\mathrm{S}(2 \mathrm{~B})=$ 2.2885(15) $\AA$; for $3, \mathrm{Ru}(1)-\mathrm{S}(1)=2.2258(9) ; \mathrm{Ru}(1)-\mathrm{S}(2)=2.291(1)$ $\AA]$ are in the same range as observed in other $\mathrm{Ru}(\mathrm{II})-\mathrm{DMSO}-\mathrm{Cl}$ complexes. ${ }^{31-33}$ The $\mathrm{S}-\mathrm{O}$ bond distance [for $1, \mathrm{~S}(1 \mathrm{~A})-\mathrm{O}(1 \mathrm{~A})=$ $1.484(4), \mathrm{S}(2 \mathrm{~A})-\mathrm{O}(3 \mathrm{~A})=1.489(5) ; \mathrm{S}(1 \mathrm{~B})-\mathrm{O}(1 \mathrm{~B})=1.478(4), \mathrm{S}(2 \mathrm{~B})-$ $\mathrm{O}(3 \mathrm{~B})=1.477(5) \AA$; for $3, \mathrm{~S}(1)-\mathrm{O}(5)=1.493(3), \mathrm{S}(2)-\mathrm{O}(6)=$ $1.487(4) \AA]$ and the $\mathrm{S}-\mathrm{C}$ bond distance $[1.784-1.790 \AA$ in 1 , $1.7745-1.797 \AA$ in 3$]$ are consistent with the values reported in the literature. ${ }^{31,34,35}$ The deviation of the bond angles in complex 1, $\mathrm{S}(1 \mathrm{~A})-\mathrm{Ru}(1 \mathrm{~A})-\mathrm{S}(2 \mathrm{~A})=92.68(6)^{\circ} ; \mathrm{S}(1 \mathrm{~B})-\mathrm{Ru} 1 \mathrm{~B}-\mathrm{S} 2 \mathrm{~B}=93.80(6)^{\circ}$ and in complex $3, \mathrm{~S}(1)-\mathrm{Ru}(1)-\mathrm{S}(2)=92.68(4)$ from $90^{\circ}$ is most probably due to steric repulsion between the DMSO molecules. The average $\mathrm{Ru}-\mathrm{N}$ bond distance fall in the range of $\mathrm{Ru}-\mathrm{N}=2.082-$ $2.086 \AA$ in 1 , and $\mathrm{Ru}-\mathrm{N}=2.083 \AA$ in 3 and are consistent with the values reported in the literature. ${ }^{33,36,37}$

\section{DNA binding studies}

UV-visible measurements. Electronic absorption spectroscopy is one of the most useful and important techniques for DNA-binding studies of metal complexes. Absorption spectra were recorded for the solutions of the complexes in the absence and in the presence of increasing concentrations of CT-DNA to evaluate the binding affinity. In the UV-visible spectra of the complexes, transition bands were observed around 250, 300 and $400 \mathrm{~nm}$. These are assigned to the predominant $\pi-\pi^{*}, \mathrm{~L}-$ delocalized ( $\mathrm{L}=$ bpy, $\mathrm{H}_{2} \mathrm{~L} 1$, and $\left.\mathrm{H}_{2} \mathrm{~L} 2\right) \mathrm{n}-\pi^{*}$ transition with shoulder and $(\mathrm{Ru} \rightarrow \mathrm{L})$ metal-to-ligand charge transfer (MLCT) based transitions respectively. The electronic spectra of the complexes are slightly different from each other in their visible region. The complexes $(12 \mu \mathrm{M})$ were titrated with varying concentrations of CT-DNA and the change in the absorption spectral profile of all the complexes at different DNA concentrations is shown in Fig. 4. The absorbance intensity of all the complexes around $300 \mathrm{~nm}$ was seen to steadily decrease with increasing DNA concentration. These DNA induced spectral changes reveal interesting interaction of the complexes with the DNA helix. The absorption spectrum of the DNA was subtracted from that of the mixtures for the ease of comparison. The addition of DNA resulted in hypochromism of about $8 \%, 15 \%$ and $6 \%$ with insignificant bathochromic shift of the complexes 1-3 respectively in the $\pi-\pi^{*}$ absorption around $300 \mathrm{~nm}$. The

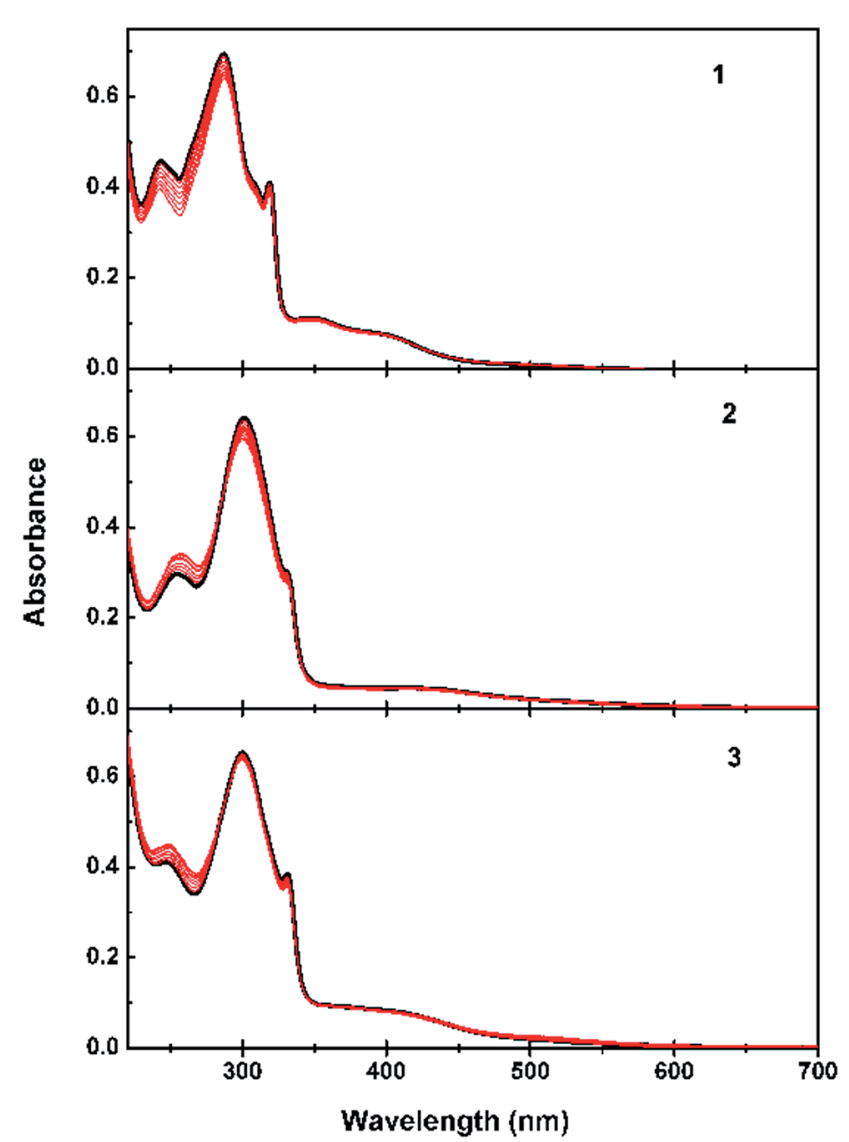

Fig. $4 U V$-visible spectra for the titration of complexes ( $12 \mu \mathrm{M}$, black) with CT-DNA $(0-110 \mu \mathrm{M})$. 
peaks can be seen to shift progressively toward a limit which represents a spectrum of the complex in a fully complexed form. Addition of DNA results in a moderate hypochromism of the absorption peaks accompanied by a minor bathochromic shift indicating that the complexes do not strongly bind to DNA with bipyridine and bipyridine dicarboxylic acid moieties and hence, intercalative binding mode may be ruled out. However, these spectral characteristics demonstrated that the complexes may bind to one of the grooves of the double helix structure of DNA via the intermolecular interactions of carboxylic acid substituents on bipyridine moiety or by ancillary ligand. The complex 2 showed significantly higher DNA binding propensity possibly due to the position of the substituent on the chelating part of bipyridine favouring considerable interaction into the DNA than complex 1 and 3. This trend suggests that the binding strength of the complex to DNA is being effectively controlled by the position of substituent.

From the observed spectral data, the intrinsic binding constants for the complexes 1-3 were calculated using the eqn (1) at the $\pi-\pi^{*}$ absorption band and the values obtained are smaller than those that observed for intercalators.

$$
[\mathrm{DNA}] /\left(\varepsilon_{\mathrm{a}}-\varepsilon_{\mathrm{f}}\right)=[\mathrm{DNA}] /\left(\varepsilon_{\mathrm{b}}-\varepsilon_{\mathrm{f}}\right)+1 /\left(K_{\mathrm{b}}\left(\varepsilon_{\mathrm{b}}-\varepsilon_{\mathrm{f}}\right)\right)
$$

where [DNA] is the concentration of DNA in base pairs, $\varepsilon_{\mathrm{a}}, \varepsilon_{\mathrm{f}}$, and $\varepsilon_{\mathrm{b}}$ are the apparent-, free- and bound-metal-complex extinction coefficients respectively. $K_{\mathrm{b}}$ is the equilibrium binding constant of complex binding to DNA. Each set of data, when fitted to the above equation, gave a straight line with a slope of $1 /\left(\varepsilon_{\mathrm{b}}-\varepsilon_{\mathrm{f}}\right)$ and a $y$-intercept of $1 / K_{\mathrm{b}}\left(\varepsilon_{\mathrm{b}}-\varepsilon_{\mathrm{f}}\right)$ and $K_{\mathrm{b}}$ was determined from the ratio of the slope to intercept (Fig. S2 and Table S2, ESI $\dagger$ ). The binding constants $K_{\mathrm{b}}$ obtained for 1,2 and 3 are $3.74 \times 10^{3} \mathrm{M}^{-1}, 1.34 \times$ $10^{4} \mathrm{M}^{-1}$ and $3.53 \times 10^{3} \mathrm{M}^{-1}$ respectively, which support appreciable groove binding of the complexes to the CT-DNA. However, further investigation is absolutely necessary to establish the exact nature of the binding of complexes to DNA.

Fluorescence competition experiment. In order to further confirm the interaction between the test compounds and CTDNA, steady-state competitive binding experiments using 1, 2 and 3 as quenchers were undertaken. Ethidium bromide (EB), a planar cationic dye has been widely used as a sensitive fluorescence probe for native DNA. Usually, EB intercalates strongly between adjacent DNA base pairs which results in emitting intense fluorescent light. As and when a quencher is added, it displaces the EB and a decrease of fluorescence results and the quenching is due to the reduction of the number of binding sites on the DNA that are available to EB. EB-DNA experiments were performed by adding increasing amounts of test solutions to the EB bound CT-DNA solution in Tris-HCl buffer. In our experiment, the EB-DNA system exhibited a strong emission band around $592 \mathrm{~nm}$. The fluorescence quenching spectra of DNA-bound EB by complexes 1, 2 and 3 shown in Fig. 5 which illustrates that, as the concentrations of the complexes increases, the emission intensity at $592 \mathrm{~nm}$ of EB-DNA system decreased in different amounts. Correlation equation and $R^{2}$ value for EB-DNA fluorescence quenching by complexes 1-3 are given in Table S3 (ESI $\dagger$ ). Upon addition of $\mathbf{1}$ and $\mathbf{3}$ to the EB-DNA system, meagre reduction in

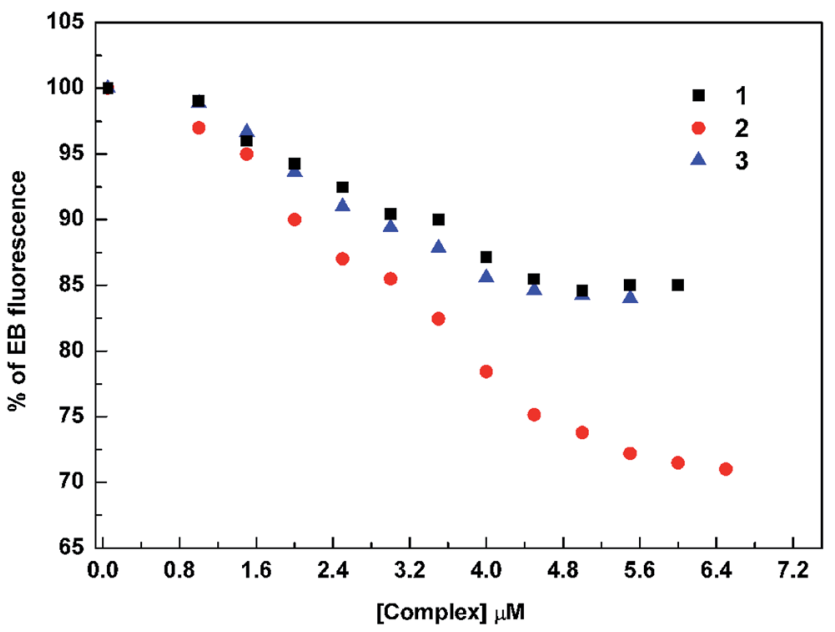

Fig. 5 Plot of EB relative fluorescence intensity (\%) vs. [complex].

emission intensities of $\mathrm{EB}$ by $16 \%$ and $15 \%$ respectively was observed, relative to that observed in the absence of complexes. On the other hand, addition of 2 to the EB-DNA mixture produced a remarkable reduction in fluorescence intensity, but the value of fluorescence intensity decreased by no more than $50 \%$. The apparent binding constant $\left(k_{\mathrm{app}}\right)$ values for the complexes could not be calculated, due to the lack of $50 \%$ of EB emission in the concentration range used in the present study. The changes observed here are characteristic of groove binding mode which is consistent with that reported earlier. ${ }^{38}$

Mechanism for the fluorescence quenching. From the fluorescence spectroscopic studies, we found that the fluorescence intensity of the EB-DNA system decreased regularly with the addition of increasing concentration of the complexes. In order to determine the type of fluorescence quenching, the fluorescence intensity of EB-DNA complex with various concentrations of ruthenium complexes 1-3 was measured at different temperatures. There are two types of quenching and they are classified as either dynamic quenching or static quenching. Dynamic and static quenching can be distinguished by their different dependencies on temperature. Dynamic quenching depends upon diffusion and it increases with increase in temperature. On the other hand there will be decrease in diffusion in case of static quenching. ${ }^{39}$

In order to confirm the quenching mechanism in our cases, the fluorescence quenching was analyzed according to SternVolmer eqn (2) at different temperatures (Fig. S3 and Table S4, ESI $\dagger$ ) and the quenching constants are given in Table 2.

$$
F_{0} / F=1+K_{\mathrm{sv}}[\mathrm{Q}]
$$

where $F_{0}$ and $F$ are the fluorescence intensities in the absence and presence of the quencher, respectively, [Q] is the concentration of the quencher and $K_{\mathrm{sv}}$ is the Stern-Volmer quenching constant.

The results in Table 2 indicate that the probable quenching mechanism of fluorescence of EB-DNA by complexes 1-3 is by static quenching since in all cases $K_{\mathrm{sv}}$ has been seen to be inversely proportional to temperature. ${ }^{40}$ 
Table 2 Stern-Volmer quenching constants of complexes-DNA system at various temperatures

\begin{tabular}{lll}
\hline Complexes & $27^{\circ} \mathrm{C}$ & $45{ }^{\circ} \mathrm{C}$ \\
\hline 1 & $3.15 \times 10^{4}$ & $2.51 \times 10^{4}$ \\
2 & $5.52 \times 10^{4}$ & $1.68 \times 10^{4}$ \\
3 & $3.02 \times 10^{4}$ & $2.56 \times 10^{4}$
\end{tabular}

DNA melting studies. The thermal behaviours of DNA in the presence of complexes can give insight into DNA conformational changes when temperature is raised. The melting temperature $T_{\mathrm{m}}$ of DNA solution, which is defined as the temperature when half of the total base pairs are unbonded or at which the double helix denatures into single stranded DNA through the breaking of hydrogen bonding between the bases, is usually introduced to study the interaction of transition metal complexes with nucleic acid. Generally, the melting temperature of DNA increases when metal complexes bind to DNA by intercalation, as intercalation of the complexes between DNA base pairs causes stabilization of base stacking and hence raises the melting temperature of double-stranded DNA. Therefore, the thermal denaturation experiment of DNA provides a convenient tool for detecting binding and also assessing relative binding strengths and hence DNA melting experiments were performed. In the present work, the thermal denaturation temperature $\left(T_{\mathrm{m}}\right)$ of unbound CT-DNA in the absence of complexes is $61.2^{\circ} \mathrm{C}$ under our experimental conditions. But, a moderate positive shift in the DNA melting temperature $\left(\Delta T_{\mathrm{m}}\right)$ is observed on the addition of the complexes to DNA (Fig. 6) and the $\Delta T_{\mathrm{m}}$ value of DNA was found to increase by $2{ }^{\circ} \mathrm{C}, 4^{\circ} \mathrm{C}$ and $2{ }^{\circ} \mathrm{C}$ upon binding to 1,2 and 3 respectively. The results primarily suggest the groove binding or electrostatic binding nature of the complexes to DNA in preference to intercalative mode of binding DNA that normally gives significantly high positive $\Delta T_{\mathrm{m}}$ values. $^{41}$

Viscometric studies. As a means for further clarifying the binding of ruthenium complexes with DNA, the viscosity of DNA

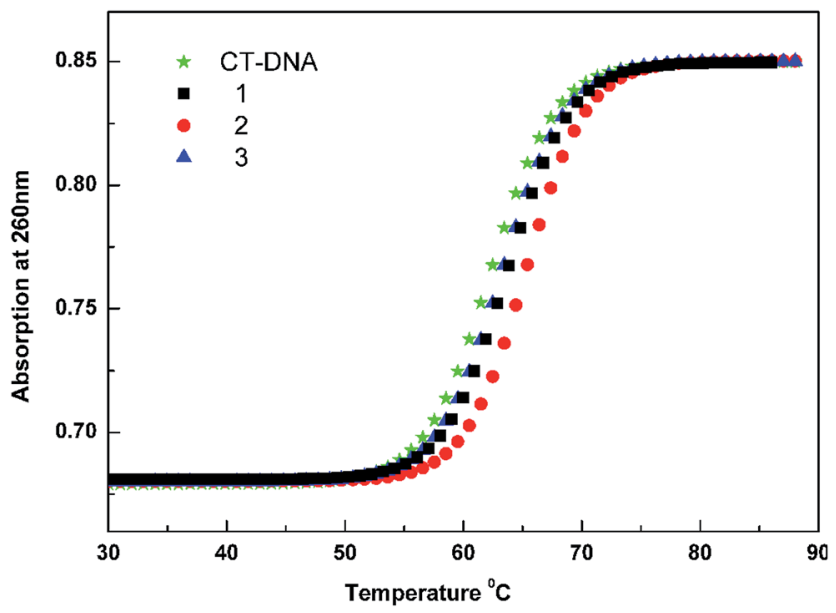

Fig. 6 Melting curves of CT-DNA in absence and presence of complexes, $[\mathrm{DNA}]=100 \mu \mathrm{M}$ and $[\mathrm{Ru}(\|)$ complex $]=12 \mu \mathrm{M}$. solutions containing varying amounts of complexes was measured. The electrostatic binding generally has no obvious effect on the viscosity of DNA, while a classical intercalation will result in lengthening of the DNA helix as base pairs are separated to accommodate the foreign molecules, leading to the increase of DNA viscosity. ${ }^{\mathbf{4 2 , 4 3}}$ The effects upon the addition of increasing concentrations of the complexes to DNA and a typical intercalator, namely EB on viscosity of DNA are shown in Fig. 7. Correlation equation and $R^{2}$ value of EB and complexes on viscosity of DNA are given in Table S5 (ESI $\dagger$ ). It is known that the drug molecules normally bind exclusively in the DNA groove (e.g., netropsin and distmycine, Hoechst 33258) typically causing a less pronounced (positive or negative) or no change in the viscosity of DNA solution. ${ }^{\mathbf{4 4 - 4 6}}$ From our viscosity measurements, it is seen that our complexes increase the viscosity of DNA but only to lesser extent as compared to EB, indicating primarily either a groove binding or surface binding nature of the complexes. Based on the change in the degree of viscosity, the binding of our complexes to DNA is in the order $\mathbf{2}>\mathbf{1} \sim \mathbf{3}$, which is consistent with our foregoing hypothesis.

Circular dichroism. CT-DNA in the B conformation exhibits two conservative circular dichroic (CD) bands, a positive band around $275 \mathrm{~nm}$ due to base stacking and a negative band around $240 \mathrm{~nm}$ due to right handed helicity. These bands are sensitive towards binding of any small molecule or drug and hence, can be exploited to investigate the binding of small molecules to DNA. ${ }^{47}$ Simple groove binding and electrostatic interactions of small molecules lead to no perturbation or marginal perturbations in these two CD bands of B-DNA. On the other hand, intercalative interaction of small molecules with DNA leads to enhancement in the intensity of $275 \mathrm{~nm}$ band and decrease in the intensity of $245 \mathrm{~nm}$ band. ${ }^{48} \mathrm{CD}$ spectra of CT-DNA in the absence as well as in the presence of increasing amounts of the test complexes were recorded and they are shown in Fig. 8. It is seen from the spectra that upon the addition of complexes to DNA, the intensity of the positive peak increased while the intensity of the negative peak decreased without any shift in the peak positions. Further, it is also noticed that the CD spectral changes for $\mathbf{2}$ are larger than

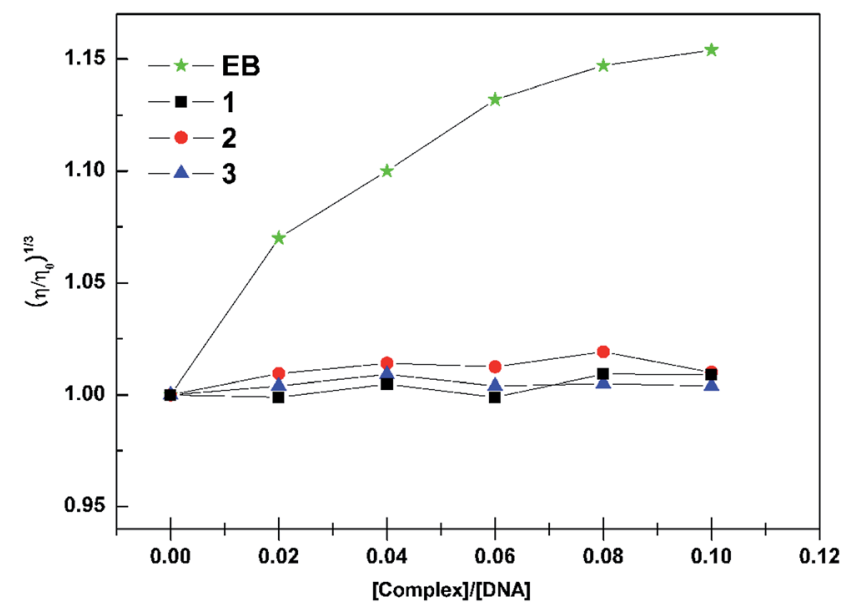

Fig. 7 Effect of the increasing amount of the complexes on the relative viscosity of CT-DNA. 


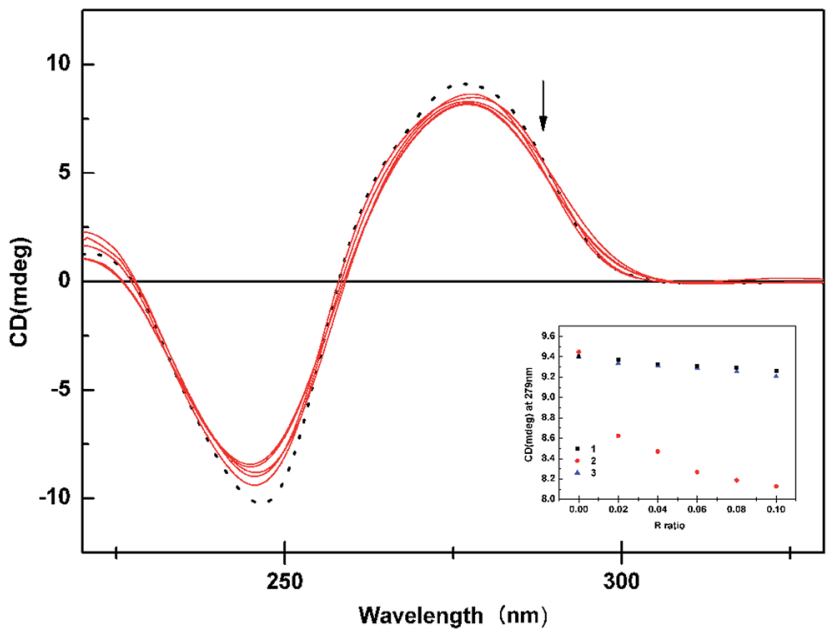

Fig. 8 CD spectrum of CT-DNA in the absence (dotted) and presence (solid) of complex 2. Inset: changes in CD intensity at $278 \mathrm{~nm}$ with respect to $R$ ratio.

those that observed for $\mathbf{1}$ and $\mathbf{3}$ indicating a better interaction of 2 with DNA, a finding which has been seen already in the absorption titrations, fluorescence quenching, DNA melting and viscosity measurements.

\section{Protein binding studies}

Since the interaction of biologically active compounds with proteins leads to either enhancement or loss of the biological properties of such compounds, it is important to study the interaction of any test compound with proteins. Hence, we have studied the interactions of our new complexes with BSA by means of UV-visible and fluorescence spectroscopy since BSA is one of the most extensively studied proteins, particularly because of its structural homology with human serum albumin (HSA). UV-visible spectra of BSA in the absence and presence of the complexes is shown in Fig. S4 (ESI $\dagger$ ). It is seen from the Fig. $\mathrm{S} 4 \uparrow$ that the absorption intensity of BSA was enhanced as the complexes were added, and there was a small red shift of about 2, 7 and $2 \mathrm{~nm}$ for the compounds 1, 2 and 3 respectively. This result suggested not only the complex formation between BSA and the test compounds but also confirms a static quenching process. ${ }^{49}$

\section{Fluorescence quenching studies of BSA}

In order to get more information on the binding of the compounds with BSA, fluorescence spectrum of BSA was studied upon the addition of the test compounds. Even though three fluorophores, namely, tryptophan, tyrosine and phenylalanine are present in BSA, the intrinsic fluorescence of BSA is mainly due to tryptophan alone ${ }^{50}$ and changes in the emission spectra of tryptophan can give information about protein conformational transitions, subunit associations, substrate binding, or denaturation. Therefore, the intrinsic fluorescence of BSA can provide considerable information on their structure and dynamics and is often employed in the study of protein folding and association reactions. Hence, the interaction of BSA with our complexes (1-3) was studied by fluorescence measurement at room temperature and from which the binding constants of the complexes were calculated. In a typical experiment, a solution of BSA $(1 \mu \mathrm{M})$ was titrated with various concentrations of the complexes $(0-35 \mu \mathrm{M})$. Fluorescence spectra were recorded in the range of 290-500 $\mathrm{nm}$ upon excitation at $280 \mathrm{~nm}$. The changes observed on the fluorescence emission spectra of a solution of BSA on the addition of increasing amounts of complexes 1-3 are shown in Fig. 9. Addition of complexes to BSA produced a dramatic modification on the emission profile. The fluorescence of BSA was quenched effectively with the red shift of $5 \mathrm{~nm}$ in the case of complex 1 and blue and red shift of 8 and $2 \mathrm{~nm}$ in the emission maximum of the complexes 2 and 3 respectively. The observed difference in the initial fluorescence of BSA is mainly due to the fact that the active site in protein is buried in a hydrophobic environment. This result indicated a definite interaction of all of the test compounds with the BSA protein.

To study the quenching process further, fluorescence quenching data were analyzed with the Stern-Volmer eqn (3) and Scatchard eqn (4). The ratio of the fluorescence intensity in the absence of $\left(I_{0}\right)$ and in the presence of $(I)$ the quencher is related to the concentration of the quencher [Q] by a coefficient $K_{\mathrm{sv}}$.

$$
I_{0} / I=1+K_{\mathrm{sv}}[\mathrm{Q}]
$$

$K_{\text {sv }}$ value obtained from the plot of $I_{0} / I v s$. [Q] was found to be $3.18 \times 10^{4} \mathrm{M}^{-1}, 1.36 \times 10^{5} \mathrm{M}^{-1}$ and $1.17 \times 10^{5} \mathrm{M}^{-1}$ corresponding to the complexes 1-3 respectively. The observed linearity in the plots (Fig. S5 and Table S6, ESI $\dagger$ ) indicated the ability of the complexes to quench the emission intensity of BSA. From $K_{\mathrm{sv}}$ values (Table 3), it can be seen that the complexes $\mathbf{2}$ and 3 exhibited strong protein-binding ability than that of $\mathbf{1}$.

For the static quenching, when molecules bind independently to a set of equivalent sites on a macromolecule, the binding constant $(K)$ and the number of binding sites $(n)$ can be determined by the Scatchard eqn (4).

$$
\log \left[\frac{F_{0}-F}{F}\right]=\log K+n \log [\mathrm{Q}]
$$

where $K$ is the binding constant of quencher with BSA, $n$ is the number of binding sites, $F_{0}$ and $F$ are the fluorescence intensity in the absence and presence of the quencher. The value of $K$ can be calculated from the slope of $\log \left[\left(F_{0}-F\right) / F\right]$ versus $\log [\mathrm{Q}]$. (Fig. S6 and Table S7, ESI $\dagger$ ). The calculated value of binding constant $(K)$ and the number of binding sites $(n)$ were listed in Table 3. The values of $n$ at room temperature are approximately equal to 1 , which indicates that there is just one single binding site in BSA for the complexes 1-3.

\section{Synchronous fluorescence spectra}

After having obtained the binding constant and binding number of the compounds with BSA, it is important to know about the conformational change of protein molecular environment in a vicinity of the fluorophore functional groups. ${ }^{51}$ The different 

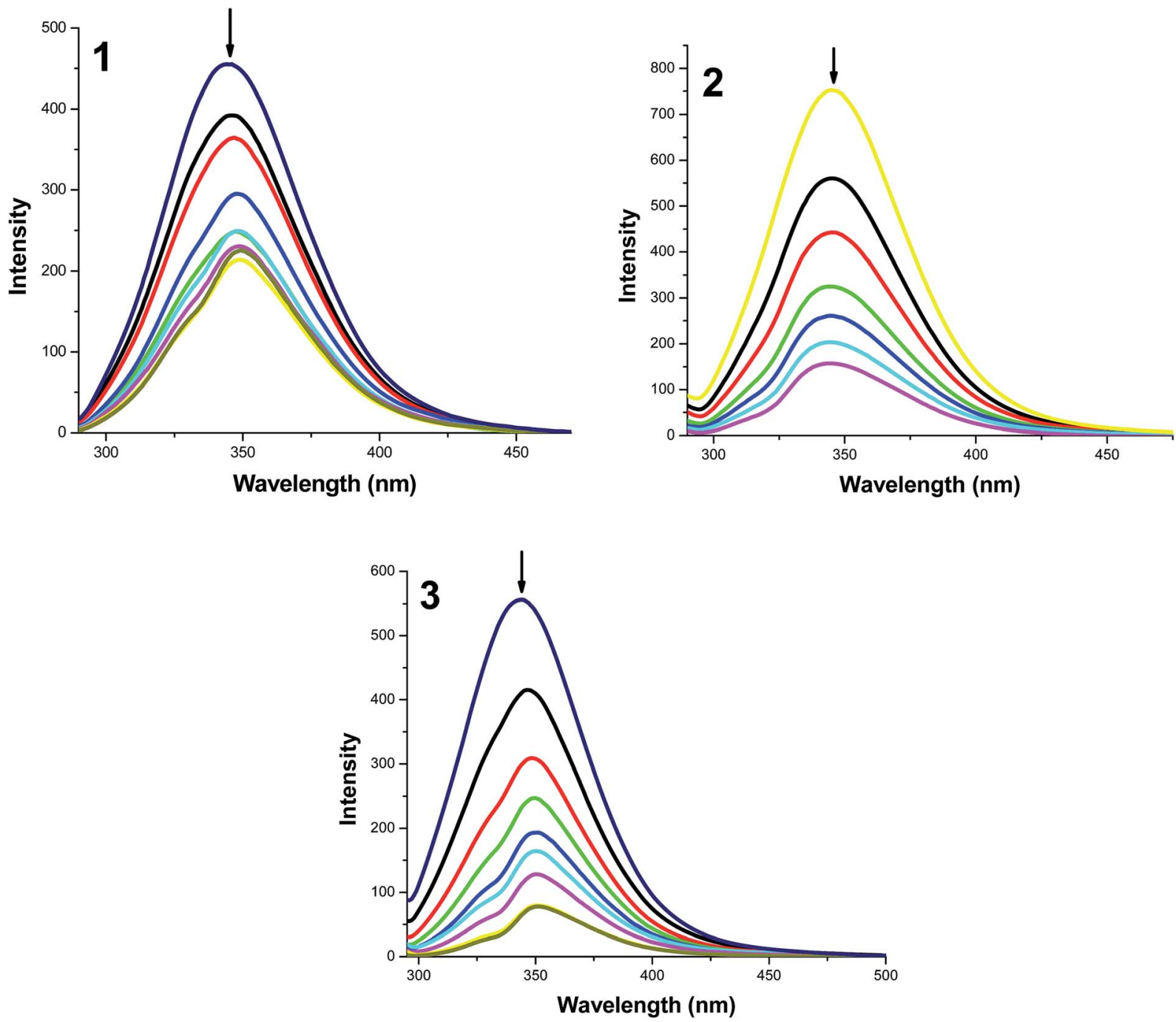

Fig. 9 The emission spectrum of BSA $\left(1 \mu \mathrm{M} ; \lambda_{\text {exc }}=280 \mathrm{~nm} ; \lambda_{\text {emi }}=345 \mathrm{~nm}\right)$ in the presence of increasing amounts of the complexes $1-3(0-35$ $\mu \mathrm{M})$. The arrow shows the fluorescence quenching upon increasing complex concentration.

Table 3 Binding constant and number of binding sites for interaction of complexes with BSA

\begin{tabular}{llll}
\hline Complexes & $K_{\text {sv }} \times \mathrm{M}^{-1}$ & $K \times \mathrm{M}^{-1}$ & $n$ \\
\hline $\mathrm{BSA}+1$ & $3.18 \times 10^{4}$ & $5.79 \times 10^{4}$ & 1.05 \\
$\mathrm{BSA}+2$ & $1.36 \times 10^{5}$ & $3.77 \times 10^{6}$ & 1.34 \\
$\mathrm{BSA}+3$ & $1.17 \times 10^{5}$ & $1.33 \times 10^{6}$ & 1.25
\end{tabular}

nature of chromophores can be found from synchronous fluorescence spectroscopy by looking at the difference between excitation and emission wavelength $\left(\Delta \lambda=\lambda_{\text {emi }}-\lambda_{\text {exc }}\right) \cdot{ }^{52}$ A value of $15 \mathrm{~nm}$ for $\Delta \lambda$ is characteristic of tyrosine residue, whereas a value of $60 \mathrm{~nm}$ is characteristic of tryptophan. ${ }^{53}$ This kind of variation in the tryptophan emission occurs due to protein conformational changes. In order to explore the structural change of BSA, we measured synchronous fluorescence spectra at $\Delta \lambda=15 \mathrm{~nm}$ (Fig. S7, ESI $\dagger$ ) and $\Delta \lambda=60 \mathrm{~nm}$ (Fig. S8, ESI $\dagger$ ) of BSA with complexes 1-3. The synchronous fluorescence spectral studies clearly suggested that the fluorescence intensities of both the tryptophan and tyrosine were affected with an increasing concentration of the complexes, which clearly indicated that the interaction of complexes with BSA affects the conformation of both the tryptophan and tyrosine micro regions. So, the strong interaction between the test compounds and BSA protein implied that these compounds can easily be stored in protein and can be released in desired targets.

Bipyridine ligand systems are extremely versatile in that small structural changes can be readily made that lead to very different chemical and physical properties. The spectroscopic results show that the carboxylic acid functionalities at different positions on the bipyridine ligand can cause some interesting differences in their DNA/protein binding properties. Since the chelating part of the ligand and ancillary ligands is same in all the three complexes the difference in binding affinity depends on the position of the - $\mathrm{COOH}$ groups at bipyridine moiety. The substitution on 5,5'-position of pyridine rings of bipyridine ligand may cause steric constraints, when the complex 
approaches the DNA base pairs and protein, thus decreasing the binding affinity of complex with DNA/protein. In complex 2 , the two $-\mathrm{COOH}$ substituents present at $4,4^{\prime}$-position of bipyridine ligand may bring some flexibility to the complex or furnish slightly tapered shape to chelating ligand which would help to approach the DNA/protein easily. This will lead to the formation of favourable H-bonding interactions with DNA groove/protein surface and two $-\mathrm{COOH}$ groups, thus resulting in the complex 2 bound to the grooves of DNA/protein more strongly. Surprisingly, the complexes $\mathbf{1}$ and $\mathbf{3}$ exhibit similar binding affinity although complex $\mathbf{1}$ does not have carboxylic acid functionality, which may be due to the less accessibility of the complex 3 towards DNA/protein and contribution of the ancillary ligands of bipyridine into the binding. It is remarkable that even seemingly minor changes in the ligand architecture and electronic structure can lead to profound effects on DNA/protein binding. These results have confirmed that the affinity magnitudes of the complexes toward DNA/protein may be controlled and tuned by playing with the position of the substituent on the chelating ligand and this strategy may be valuable in understanding the DNA/protein binding properties of the complexes containing bipyridine and bipyridine dicarboxylic acids as well as laying a foundation for the rational design of novel, powerful agents for probing and targeting nucleic acids.

\section{Antioxidant activity studies}

Since the experiments carried out so far revealed that the new ruthenium complexes exhibit reasonable DNA and protein binding affinity, it is considered worthwhile to test their ability to quench the free radicals and study their antioxidant properties. Usually free radicals are generated in many bioorganic redox processes and they induce oxidative damage in various components of the body (lipids, proteins and DNA) and they have been implicated in chronic diseases such as cancer, hypertension, Parkinson disease, Alzheimer, cardiac infarction, atherosclerosis, rheumatism, cataracts etc. ${ }^{54,55}$ Efforts to counteract the damage caused by the free radicals are gaining acceptance as an origin for novel therapeutic approaches and the field of preventive medicine is experiencing an upsurge of interest in medically useful antioxidants.

The in vitro antioxidant properties of ruthenium complexes have attracted a lot of interest, but the radical scavenging activity is limited to hydroxyl radical. ${ }^{56}$ Hence, we carried out experiments to investigate the free radical scavenging ability of the new ruthenium complexes against a panel of free radicals, with a hope to develop potential antioxidants and therapeutic reagents. The $\mathrm{IC}_{50}$ value of all the complexes (Table 4) obtained from different types of assay experiments strongly supports that the new complexes possess good antioxidant activities, which are much better than that of the standard antioxidants vitamin $\mathrm{C}$ and BHT.

Antioxidants exert their effect by different mechanisms such as scavenging or inhibiting free radicals by the donation of an electron or proton $\left(\mathrm{H}^{+}\right)$or chelation of metal ions that otherwise may lead to free radical formation. From the radical scavenging data (Table 4), it can be seen that complexes 2 and 3 showed better radical scavenging activity than complex $\mathbf{1}$. This might be due to the presence of free carboxylic acid groups in the bipyridine moiety of 2 and 3 thus making those complexes efficient hydrogen donors to stabilize the unpaired electrons and thereby scavenging the free radicals. Out of the five radical species chosen to examine, the DPPH radical scavenging power of the tested complexes was the most (9.44 \pm $1.21 \mu \mathrm{M})$, and the hydrogen peroxide scavenging ability was the least $(208.49 \pm 5.19 \mu \mathrm{M})$. The antioxidant ability of any compound besides being related with the hydrogen atom transfer reaction could also be due to its capacity to chelate metal ions and/or inhibit oxidative enzymes. Earlier investigations have shown that the participation of perferryl complex $\left(\mathrm{ADP}-\mathrm{Fe}^{3+}-\mathrm{O}_{2}{ }^{-\bullet}\right)$ in the initiation and propagation of lipid peroxidation, indicating the requirement of oxygen and free iron. ${ }^{57}$ Hence, it is inferred that the presence of molecules with the ability to chelate metal ions could reduce the reactive species which will lead to the protection of lipid membranes against peroxidation. Hence, we studied the metal chelating capacity of our compounds with $\mathrm{Fe}^{2+}$ ion which showed that the complexes exhibited moderate to high metal chelating activity which might be due to the chelation of $\mathrm{Fe}^{2+}$ ion by the uncoordinated $\mathrm{COOH}$ group. A plausible mechanism for metal chelating and DPPH scavenging activity of the complexes is given in Fig. S9 (ESI $\dagger$ ). The appropriate attachment of $\mathrm{COOH}$ group $\left(\mathrm{H}^{+}\right.$donation and $\mathrm{COO}^{-}$chelation) is only the responsible factor, which makes $\mathbf{2}$ and $\mathbf{3}$ superior to $\mathbf{1}$ in all the radical scavenging assays including metal chelating activity. Though the structural differences between the two compounds $\mathbf{2}$ and $\mathbf{3}$ are not very pronounced, the complex $\mathbf{3}$ displayed better antioxidant activity than 2 in of all assays, suggesting that the possible intramolecular hydrogen bonding formation

Table 4 Antioxidant activity of the new complexes, vitamin $\mathrm{C}$ and $\mathrm{BHT}$ against various radicals

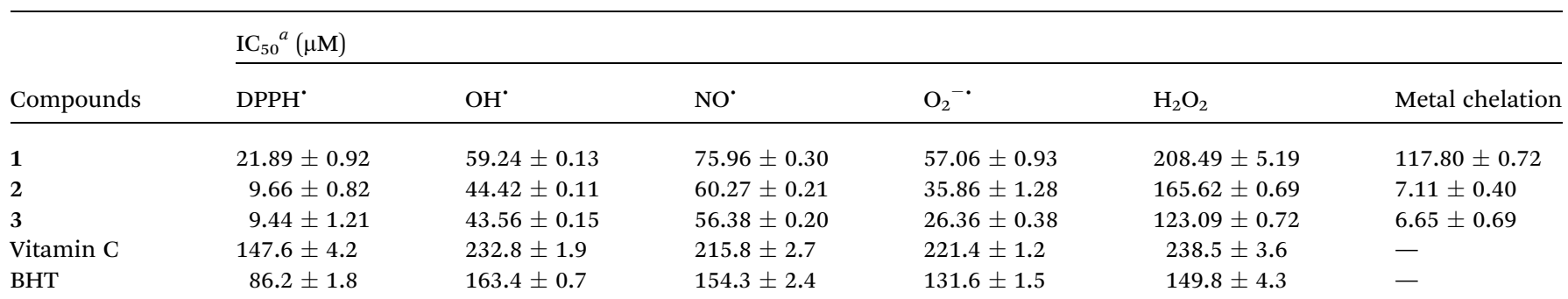

${ }^{a}$ Fifty percent inhibitory concentration of the test compounds against free radicals. 
in 2 may hinder the donation of $\mathrm{H}^{+}$in neutralizing the free radicals. The metal chelating and $\mathrm{DPPH}$ radical scavenging ability of the new complexes are better than those that were previously reported by us for other ruthenium(II) complexes comprising dicarboxylic acids. ${ }^{58,11 c}$

\section{Anticancer activity studies}

Since the results of antioxidant activity experiments revealed that the new complexes exhibit good antioxidant activity, we switched over our study to anticancer activity evaluation because nowadays it has been strongly suspected that cancer may be one of those degenerative disease induced by free radicals. Further, substantial evidence supports the active involvement of free radicals in the development of several pathological conditions including neurodegenerative and cardiovascular diseases, diabetes, cancer or even normal aging. To study cytotoxic activity of the new complexes on cancer cells, the SRB test was used. Moreover, since the balance between the therapeutic potential and toxic side effects of a compound is very important when evaluating its usefulness as a pharmacological drug, experiments were also designed to investigate the in vitro cytotoxic selectivity of synthesized ruthenium complexes against normal cells by MTT assay. The cytotoxic activity study was carried with the complexes 1-3, using five different cancer cell lines HeLa, HCT-15, SKOV3, MCF7, SKMel2 and two normal cell lines NIH 3T3, HEK 293. The effects of the test compounds on the viability of these cells were evaluated after an exposure period of $48 \mathrm{~h}$. The cells were treated with different concentrations of the test compounds. The test compounds were dissolved in DMSO and the blank samples containing same volume of DMSO were taken as controls to identify the activity of the solvent in the cytotoxicity experiment. In parallel, the influence of ruthenium anticancer drug NAMI A and widely used platinum anticancer drug, cisplatin have also been assayed as a positive control. The $\mathrm{IC}_{50}$ values for three new ruthenium complexes 1-3, NAMI A and cisplatin for selected cell lines are shown in Table 5 . In the case of all the cancer cells tested, it is interesting to observe that while complex $\mathbf{1}$ is not active, complexes 2 and $\mathbf{3}$ show some cytotoxic activity against cell lines, although the activities are lower than those exhibited by cisplatin which is very common for ruthenium based anticancer agents. ${ }^{40}$ However, while comparing the cytotoxicity of the new complexes with NAMI A, they displayed better activity corresponding to inhibition over NAMI A in almost all the cancer cells tested. The lack of cytotoxic activity of $\mathbf{1}$ was expected in view of its specific structure i.e. the absence of $\mathrm{COOH}$; by contrast, the activity of $\mathbf{2}$ and $\mathbf{3}$ toward the cancer cell lines is quite striking in view of the presence of the carboxylic acid arm in the bipyridine ligand. As evaluated by their $\mathrm{IC}_{50}$ values, 2 and 3 displayed better cytotoxic activity against SKOV3 cells when compared to the other cancer cells screened. 1 did not show any significant activity even up to $500 \mu \mathrm{M}$ concentration on HeLa and MCF7 cells. The results of MTT assay also indicated that the IC $_{50}$ values of complexes 2 and 3 against NIH 3T3 and HEK 293 cells are found to be above $1000 \mu \mathrm{M}$, which confirmed that the complexes are very specific on cancer cells and even less toxic compared to NAMI A ( IC $_{50(\mathrm{NIH} 3 \mathrm{~T} 3)}=570 \mu \mathrm{M} ; \mathrm{IC}_{50(\mathrm{HEK} 293)}=533$ $\mu \mathrm{M})$ and cisplatin $\left(\mathrm{IC}_{50(\mathrm{NIH}} 3 \mathrm{~T} 3\right)=175 \mu \mathrm{M} ; \mathrm{IC}_{50 \text { (HEK 293) }}=115$ $\mu \mathrm{M})$. Considering the specific structures of $\mathbf{1}$ and 2, 3, it appears that the carboxyl moiety of $\mathbf{2}$ and $\mathbf{3}$ may play a critical role for the observed cytotoxic activity and selectivity on the tested cell lines. The COOH group could not easily penetrate the hydrophobic cellular membrane of noncancerous cells but could readily bind to certain biomolecules over expressed on surfaces of the rapidly growing cancer cells. The activity results suggest a variation of cell sensitivity in the cell lines studied and was in the sequence of $2 \sim 3>\mathbf{1}$, which is consistent with the trends of their radical scavenging abilities. Another generalization is that there is no substantial variation in the cytotoxic activities when the position of $\mathrm{COOH}$ in the bipyridine moiety of the complexes was changed. Though the new ruthenium complexes did not show significant in vitro cytotoxicity, further studies are needed to assess their antiproliferative activity in vivo and to elucidate the actual mechanism of the anti-tumor activity. But the cytotoxicity and selectivity of the synthesized complexes may be improved by introducing more carboxylic acid functionalities, other functional groups like sulphonic acid, ester, methoxy, amine, DNA intercalating terpyridine, phenanthroline moieties and one or more ruthenium ions in the form of bi or polynuclear ruthenium complexes.

\section{Conclusion}

The present contribution describes the synthesis and characterization of two types of three new ruthenium(II) complexes. One is composed by bipyridine moiety with $\mathrm{COOH}$ and the

Table $5 \quad I_{50}(\mu M)$ ruthenium complexes, NAMI A and cisplatin against various cancer and normal cells

\begin{tabular}{|c|c|c|c|c|c|c|c|}
\hline \multirow[b]{3}{*}{ Complexes } & \multicolumn{7}{|l|}{$\underline{\mathrm{IC}_{50}{ }^{a}(\mu \mathrm{M})}$} \\
\hline & \multicolumn{5}{|l|}{ SRB assay } & \multicolumn{2}{|c|}{ MTT assay } \\
\hline & HCT-15 & HeLa & SKOV3 & MCF7 & SKMel2 & NIH 3T3 & HEK 293 \\
\hline 1 & $376.23 \pm 2.20$ & $>500$ & $241.76 \pm 1.22$ & $>500$ & $357.22 \pm 3.50$ & $235 \pm 1$ & $197 \pm 2$ \\
\hline 2 & $227.74 \pm 0.08$ & $380.34 \pm 0.58$ & $192.98 \pm 1.47$ & $258.00 \pm 0.55$ & $279.42 \pm 0.39$ & $>1000$ & $>1000$ \\
\hline 3 & $208.12 \pm 0.59$ & $291 \pm 0.11$ & $189.47 \pm 0.14$ & $227.74 \pm 1.47$ & $235.76 \pm 1.60$ & $>1000$ & $>1000$ \\
\hline NAMI A & $>500$ & $>500$ & $>500$ & $>500$ & $>500$ & $570 \pm 4$ & $533 \pm 3$ \\
\hline Cisplatin & $45.49 \pm 0.40$ & $54.00 \pm 0.7$ & $32.56 \pm 1.36$ & $18.73 \pm 0.28$ & $25.53 \pm 0.3$ & $175 \pm 2$ & $115 \pm 5$ \\
\hline
\end{tabular}

${ }^{a}$ Fifty percent inhibitory concentration after exposure for $48 \mathrm{~h}$. 
other is only with the bipyridine moiety and two chlorides and dimethylsulphoxides are common to both. In both the cases, ruthenium is bonded to the nitrogen atoms of the bipyridine ring, which is confirmed by single crystal X-ray crystallographic studies. The groove binding of the mentioned complexes with DNA was deduced by taking account of relevant UV-visible absorption spectra, fluorescence spectra, DNA melting, viscosity measurements and circular dichroism. The protein binding properties of the complexes were examined by the fluorescence spectra and a greater binding affinity was observed for the complexes $\mathbf{2}$ and $\mathbf{3}$ over $\mathbf{1}$. The incorporation and position of $\mathrm{COOH}$ group in the bipyridine ring played a significant role in modulating the DNA/protein binding behaviours of the complexes. Moreover, the results obtained from various antioxidant assays and cytotoxic studies showed that the complexes 2 and 3 showed good radical scavenging ability, moderate cytotoxic activity and greater cytotoxic selectivity over $\mathbf{1}$. It is seen from the results that the introduction of $\mathrm{COOH}$ group in the bipyridine ring markedly increased the antitumor and antioxidant efficiency of the new complexes. We can envision this to open up new avenues for the designing and screening of the suitable ruthenium complexes containing free $\mathrm{COOH}$ group for anticancer activity studies.

\section{Electronic supplementary information}

${ }^{1} \mathrm{H}$ NMR spectrum of complex 1 (Fig. S1†); selected geometrical parameters for complexes 1 and 3 (Table S1 $\dagger$ ); plot of [DNA]/( $\varepsilon_{a}$ $\left.-\varepsilon_{\mathrm{f}}\right) v s$. [DNA] for the titration of CT-DNA with complexes 1-3 (Fig. S2 $\dagger$ ); correlation equation and $R^{2}$ value of the complexes 13 for plot of [DNA]/( $\left.\varepsilon_{\mathrm{a}}-\varepsilon_{\mathrm{f}}\right) v s$. [DNA] (Table S2 $\dagger$ ); correlation equation and $R^{2}$ value for EB-DNA fluorescence quenching by complexes 1-3 (Table S3†); Stern-Volmer plots for EB-DNA quenching by the ruthenium complexes at different temperatures (Fig. S3†); correlation equation and $R^{2}$ value of 1-3 for Stern-Volmer plots for EB-DNA quenching by the ruthenium complexes at different temperatures (Table S4 $\dagger$ ); correlation equation and $R^{2}$ value of EB and complexes on viscosity of DNA (Table S5 $†$ ); UV-visible absorption spectra of BSA in the absence and presence of the complexes 1-3 (Fig. S4 $\dagger$ ); plot of $I_{0} / I v s$. log [Q] (Fig. S5 $\dagger$ ); correlation equation and $R^{2}$ value of complexes 13 for plot of $I_{0} / I v s$. $\log [\mathrm{Q}]$ (Table S6 $\dagger$ ); plot of $\log \left[\left(F_{0}-F\right) / F\right] v s$. $\log [\mathrm{Q}]$ (Fig. S6 $\dagger$ ); correlation equation and $R^{2}$ value of the complexes 1-3 for plot of $\log \left[\left(F_{0}-F\right) / F\right] v s . \log [\mathrm{Q}]$ (Table S7†); synchronous spectra of BSA in the presence of increasing amounts of the complexes 1-3 for a wavelength difference of $\Delta \lambda$ $=15 \mathrm{~nm}$ (Fig. S7 $\uparrow$ ); synchronous spectra of BSA in the presence of increasing amounts of the complexes 1-3 for a wavelength difference of $\Delta \lambda=60 \mathrm{~nm}$ (Fig. S8 $\dagger$ ); plausible mechanisms for DPPH radical scavenging and metal chelating activity for complex 3 (Fig. S9†); CCDC reference numbers 869937 and 843881 .

\section{Acknowledgements}

Council of Scientific and Industrial Research, New Delhi, India, for the award of Senior Research Fellowship to T. Sathiya
Kamatchi is gratefully acknowledged. We would like to thank Dr P. Kalaivani for her help in carrying out the protein binding studies. Acknowledgment is also made to Mr S. Saravanan and Dr T. Parimelazhagan, Department of Botany, Bharathiar University, India for their help in radical scavenging assays.

\section{References}

1 (a) B. A. Chabner and T. G. Roberts, Nat. Rev. Cancer, 2005, 5, 65-72; (b) J. Bernier, E. J. Hall and A. Giaccia, Nat. Rev. Cancer, 2004, 4, 737-747.

2 M. Galanski, V. B. Arion, M. A. Jakupec and B. K. Keppler, Curr. Pharm. Des., 2003, 9, 2078-2089.

3 M. A. Jakupec, M. Galanski and B. K. Keppler, Rev. Physiol., Biochem. Pharmacol., 2003, 146, 1-53.

4 M. Galanski, M. A. Jakupec and B. K. Keppler, Curr. Med. Chem., 2005, 12, 2075-2094.

5 (a) G. Daugaard and U. Abildgaard, Cancer Chemother. Pharmacol., 1989, 25, 1-9; (b) V. Pinzani, F. Bressolle, I. J. Haug, M. Galtier, J. P. Blayac and P. Balmes, Cancer Chemother. Pharmacol., 1994, 35, 1-9; (c) D. Screnci and M. J. McKeage, J. Inorg. Biochem., 1999, 77, 105-110; (d) L. Troy, K. McFarland, S. Littman-Power, B. J. Kelly, E. T. Walpole, D. Wyld and D. Thomson, Psycho Oncol., 2000, 9, 29-39; (e) M. Markman, Expert Opin. Drug Saf., 2003, 2, 597-607; (f) P. C. Bruijnincx and P. J. Sadler, Curr. Opin. Chem. Biol., 2008, 12, 197-206; (g) K. Barabas, R. Milner, D. Lurie and C. Adin, Vet. Comp. Oncol., 2008, 6, 1-18; (h) P. Borst, S. Rottenberg and J. Jonkers, Cell Cycle, 2008, 7, 1353-1359.

6 (a) M. J. Clarke, F. C. Zhu and D. R. Frasca, Chem. Rev., 1999, 99, 2511-2533; (b) R. H. Fish and G. Jaouen, Organometallics, 2003, 22, 2166-2177.

7 (a) C. S. Allardyce and P. J. Dyson, Platinum Met. Rev., 2001, 45, 62-69; (b) M. J. Clarke, Coord. Chem. Rev., 2003, 236, 209-233; (c) Y. K. Yan, M. Melchart, A. Habtemariam and P. J. Sadler, Chem. Commun., 2005, 38, 4764-4776; (d) P. J. Dyson and G. Sava, Dalton Trans., 2006, 16, 1929-1933; (e) M. Melchart and P. J. Sadler, in Bioorganometallics: Biomolecules, Labeling, Medicine, ed. G. Jaouen, Wiley-VCH, New York, 2006, pp. 39-62; $(f)$ A. Levina, A. Mitra and P. A. Lay, Metallomics, 2009, 1, 458-470; (g) I. Bratsos, T. Gianferrara, E. Alessio, C. G. Hartinger, M. A. Jakupec and B. K. Keppler, in Bioinorganic Medicinal Chemistry, ed. E. Alessio, Wiley-VCH, Weinheim, 2011, pp. 151-174; $(h)$ S. B. Fricker, Dalton Trans., 2007, 4903-4917.

8 I. Bratsos, S. Jedner, T. Gianferrara and E. Alessio, Chimia, 2007, 61, 692-697.

9 (a) F. Frausin, V. Scarcia, M. Cocchietto and G. Sava, J. Pharmacol. Exp. Ther., 2005, 313, 227-233; (b) B. Serli, E. Zangrando, T. Gianferrara, L. Yellowlees and E. Alessio, Coord. Chem. Rev., 2003, 245, 73-83; (c) G. Sava, R. Gagliardi, A. Bergamo, E. Alessio and G. Mestroni, Anticancer Res., 1999, 19, 969-972.

10 E. Alessio, Chem. Rev., 2004, 104, 4203-4242.

11 (a) C. M. Giandomenico, M. J. Abrams, B. A. Murrer, J. F. Vollano, M. I. Rheinheimer, S. B. Wyer, G. E. Bossard 
and J. D. Higgins, Inorg. Chem., 1995, 34, 1015-1021; (b) M. Galanski and B. K. Keppler, Inorg. Chem., 1996, 35, 1709-1711; (c) T. Sathiya Kamatchi, N. Chitrapriya, H. Lee, F. R. Fronczek and K. Natarajan, Eur. J. Med. Chem., 2013, 59, 253-264.

12 (a) H. Y. Mei and J. K. Barton, Proc. Natl. Acad. Sci. U. S. A., 1988, 85(5), 1339-1343; (b) V. Brabec, Prog. Nucleic Acid Res. Mol. Biol., 2002, 71, 1-68; (c) B. M. Zeglis, V. C. Pierre and J. K. Barton, Chem. Commun., 2007, 44, 4565-4579; (d) C. Gaiddon, P. Jeannequin, P. Bischoff, M. Pfeffer, C. Sirlin and J. P. Loeffler, J. Pharmacol. Exp. Ther., 2005, 315(3), 1403-1411; (e) R. L. Hayward, Q. C. Schornagel, R. Tente, J. S. Macpherson, R. E. Aird and S. Guichard, Cancer Chemother. Pharmacol., 2005, 55(6), 577-583; (f) S. Chatterjee, S. Kundu, A. Bhattacharyya, C. G. Hartinger and P. J. Dyson, J. Biol. Inorg Chem., 2008, 13(7), 11491155; $(g)$ B. Wu, M. S. Ong, M. Groessl, Z. Adhireksan, C. G. Hartinger, P. J. Dyson and C. A. Davey, Chem.-Eur. J., 2011, 17, 3562-3566.

13 K. B. Beckman and B. N. Ames, Phys. Rev., 1998, 78, 447453.

14 B. Halliwel and J. M. C. Gutteridge, Free Radicals in Biology and Medicine, Clarendon Press, Oxford, 2nd edn, 1989, pp. 416-494.

15 I. P. Evans, A. Spencer and G. Wilkinson, J. Chem. Soc., Dalton Trans., 1973, 2, 204-209.

16 O. V. Dolomanov, L. J. Bourhis, R. J. Gildea, J. A. K. Howard and H. Puschmann, OLEX2: a complete structure solution, refinement and analysis program, J. Appl. Crystallogr., 2009, 42, 339-341.

17 L. J. Bourhis, O. V. Dolomanov, R. J. Gildea, J. A. K. Howard and H. Puschmann, olex2.solve, 2011.

18 G. M. Sheldrick, Acta Crystallogr., Sect. A: Found. Crystallogr., 2008, 64, 112-122.

19 M. C. Altomare, M. Burla, G. L. Camalli, C. Cascarano, A. Giacovazzo, A. G. G. Guagliardi, G. Moliterni and R. Polidori, J. Appl. Crystallogr., 1999, 32, 115-119.

20 L. J. Farrugia, J. Appl. Crystallogr., 1997, 30, 565-566.

21 M. S. Blois, Nature, 1958, 29, 1199-1200.

22 T. Nash, J. Biochem., 1953, 55, 416-421.

23 L. C. Green, D. A. Wagner, J. Glogowski, P. L. Skipper, J. S. Wishnok and S. R. Tannenbaum, Anal. Biochem., 1982, 126, 131-138.

24 R. J. Ruch, S. J. Cheng and J. E. Klaunig, Carcinogenesis, 1989, 10, 1003-1008.

25 C. Beauchamp and I. Fridovich, Anal. Biochem., 1971, 44, 276-287.

26 T. C. P. Dinis, V. M. C. Madeira and L. M. Almeida, Arch. Biochem. Biophys., 1994, 315, 161-169.

27 R. E. Marsh, V. Schomaker and F. H. Herbstein, Acta Crystallogr., Sect. B: Struct. Sci., 1998, 54, 921-924.

28 E. Alessio, G. Mestroni, G. Nardin, W. M. Attia, M. Calligaris, G. Sava and S. Zorzet, Inorg. Chem., 1988, 27, 4106-4113.

29 M. Trivedi, Y. K. Sharma, R. Nagarajan and N. P. Rath, J. Mol. Struct., 2010, 975, 335-342.
30 J. Mola, I. Romero, M. Rodriguez, F. Bozoglian, A. Poater, M. Sola, T. Parella, J. Benet-Buchholz, X. Fontrodona and A. Llobet, Inorg. Chem., 2007, 46(25), 10707-10716.

31 E. Reisner, V. B. Arion, A. Rufinska, I. Chiorescu, W. F. Schmid and B. K. Keppler, Dalton Trans., 2005, 21(14), 2355-2364.

32 M. B. Cingi, M. Lanfranchi, M. A. Pellinghelli and M. Tegoni, Eur. J. Inorg. Chem., 2000, 703-711.

33 C. Tan, S. Hu, J. Liu and L. Ji, Eur. J. Med. Chem., 2011, 46, 1555-1563.

34 I. Bratsos, B. Serli, E. Zangrando, N. Katsaros and E. Alessio, Inorg. Chem., 2007, 46, 975-992.

35 M. Calligaris, Coord. Chem. Rev., 2004, 248, 351-375.

36 I. Bratsos, D. Urankar, E. Zangrando, P. Genova-Kalou, J. Kosmrlj, E. Alessio and I. Turel, Dalton Trans., 2011, 40, 5188-5199.

37 C. Sens, M. Rodriguez, I. Romero, A. Llobet, T. Parella, B. P. Sullivan and J. Benet-Buchholz, Inorg. Chem., 2003, 42, 2040-2048.

38 D. J. Patel, Acc. Chem. Res., 1979, 12, 118-125.

39 (a) G. Z. Chen, X. Z. Haong, J. C. Xu, Z. Z. Zhang and Z. B. Wang, The methods of Fluorescence Analysis, Beijing Science Press, 2nd edn, 1990, pp. 2-112; (b) Y. Lu, Y. L. Wang, S. H. Gao, G. K. Wang, C. L. Yan and D. J. Chen, J. Lumin., 2009, 129, 1048-1054; (c) S. Ashoka, J. Seetharamappa, P. B. Kandagal and S. M. T. Shaikh, J. Lumin., 2006, 121, 179-186.

40 J. Chen, X. Y. Jiang, X. Q. Chen and Y. Chen, J. Mol. Struct., 2008, 876, 121-126.

41 (a) M. J. Han, L. H. Gao and K. Z. Wang, New J. Chem., 2006, 30, 208-214; (b) Y. Z. Ma, H. J. Yin and K. Z. Wang, J. Phys. Chem. B, 2009, 113, 111039-111047.

42 S. Satyanarayana, J. C. Dabrowiak and J. B. Chaires, Biochemistry, 1993, 32, 2573-2584.

43 Y. Wang, G. Lin, J. Hong, T. Lu, L. Li, N. Okabe and M. Odoko, Inorg. Chim. Acta, 2009, 362, 377-384.

44 E. C. Long and J. K. Barton, Acc. Chem. Res., 1990, 23, 271273.

45 D. Suh and J. B. Chaires, Bioorg. Med. Chem., 1995, 3(6), 723728.

46 L. Lerman, J. Mol. Biol., 1961, 3, 18-30.

47 B. Norden and F. Tjerneld, Biopolymers, 1982, 21, 1713-1734.

48 P. T. Selvi and M. Palaniandavar, Inorg. Chim. Acta, 2002, 337, 420-428.

49 H. Y. Liu, Z. H. Xu, X. H. Liu, P. X. XI and Z. Z. Zeng, Chem. Pharm. Bull., 2009, 57, 1237-1242.

50 A. Sulkowska, J. Mol. Struct., 2002, 614, 227-232.

51 G. Z. Chen, X. Z. Huang, J. G. Xu, Z. B. Wang and Z. Z. Zhang, Method of Fluorescent Analysis, Science Press, Beijing, 2nd edn, 1990, vol. 126, ch. 4, p. 123.

$52 \mathrm{~J} . \quad$ N. Miller, Recent advances in molecular luminescence analysis, Proc. Anal. Div. Chem. Soc., 1979, 16, 203-208.

53 J. H. Tang, F. Luan and X. G. Chen, Bioorg. Med. Chem., 2006, 49, 3210-3217. 
54 K. Tsai, T. G. Hsu, K. M. Hsu, H. Cheng, T. Y. Liu, C. F. Hsu and C. W. Kong, Free Radical Biol. Med., 2001, 31, 14651472.

55 C. S. Rivas, J. C. Espin and H. Wichers, Phytochem. Anal., 2000, 11, 330-338.

56 (a) H. L. Huang, Y. J. Liu, C. H. Zeng, J. H. Yao, Z. H. Liang, Z. Z. Li and F. H. Wu, J. Mol. Struct., 2010, 966, 136-143; (b) Y. J. Liu, C. H. Zeng, Z. H. Liang, J. H. Yao, H. L. Huang, Z. Z. Li and F. H. Wu, Eur. J. Med. Chem., 2010, 45, 30873095; (c) X. L. Hong, H. Li and C. H. Peng, J. Mol. Struct.,
2011, 990, 197-203; (d) Z. Z. Li, Z. H. Liang, H. L. Huang and Y. J. Liu, J. Mol. Struct., 2011, 1001, 36-42; (e) Y. J. Liu, Z. H. Liang, Z. Z. Li, J. H. Yao and H. L. Huang, J. Organomet. Chem., 2011, 696, 2728-2735.

57 K. Kogure, H. Sassa, K. Abe, K. Kitahara, Y. Sano, H. Kawano, Y. Nakagawa and H. Terada, Biol. Pharm. Bull., 1998, 21, 180183.

58 T. Sathiya Kamatchi, N. Chitrapriya, S. K. Kim, F. R. Fronczek and K. Natarajan, Dalton Trans., 2012, 41, 2066-2077. 